\title{
ARTICLE \\ EUROPEAN UNION CITIZENSHIP AND THE UNLAWFUL DENIAL OF MEMBER STATE NATIONALITY
}

\author{
William Thomas Worster*
}

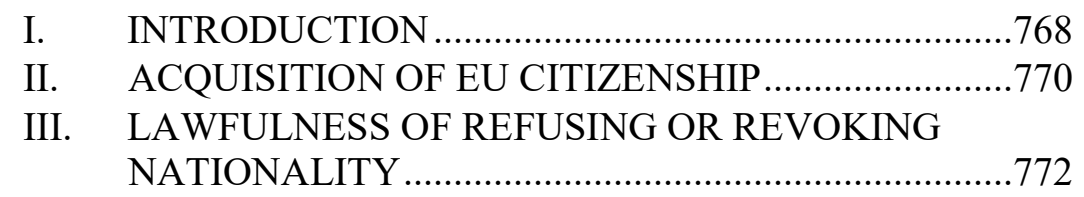

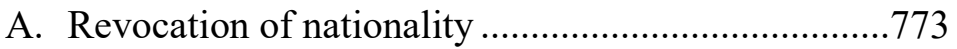

1. European regional law ........................................775

2. International law ............................................ 780

a. Statelessness ............................................780

b. Arbitrary or discriminatory measures ..........782

c. Other issues...................................................786

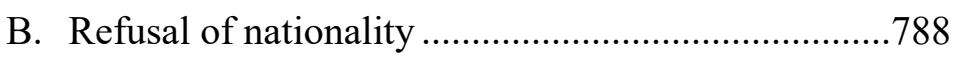

1. European regional law ........................................788

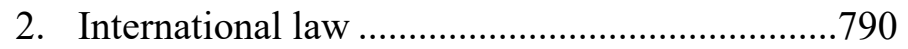

a. Nationality at birth .....................................791

b. Naturalization ...............................................793

IV. CONSEQUENCES OF THE UNLAWFUL DENIAL OF

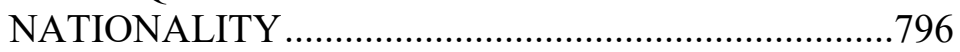

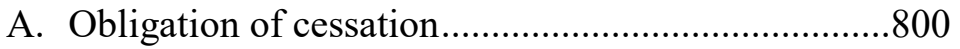

B. Obligation to refuse to recognize an unlawful act....802

1. Jus cogens ...................................................... 802

2. Ex injuria jus non oritur .................................809

\footnotetext{
* Senior Lecturer, International Law, The Hague University of Applied Sciences, The Hague, The Netherlands; Ph.D. candidate in International Law, University of Amsterdam, Amsterdam, The Netherlands; LL.M. (Adv.) in Public International Law, cum laude, Leiden University, Leiden, The Netherlands; J.D., Chicago-Kent College of Law, Illinois Institute of Technology, Chicago, Illinois.
} 


\section{INTRODUCTION}

Increasingly some European Union ("EU") Member States are undertaking practices to revoke or refuse nationality and thus EU citizenship, yet some of these practices are unlawful. It does not seem correct that a Member State's unlawful act would have the result of denying an individual EU citizenship, but in principle EU Member States are the gatekeepers to EU citizenship. This Article will question the impact of measures denying nationality on EU citizenship, and conclude that, when an EU Member State unlawfully denies nationality, the person can nonetheless still acquire EU citizenship.

Whether a person acquires the nationality of the state largely falls within the discretion of the state, and international law plays little role. This practice is true for both acquisition and withdrawal of nationality, although those two processes have slightly different rules. In general, the revocation of nationality is not prohibited by international law; ${ }^{1}$ however, that general rule is increasingly subjected to several exceptions.

This general rule is also applicable within the European Union. The nationals of EU Member States acquire EU citizenship as an automatic legal consequence of their nationality and their state's membership in the European Union. In line with the general rule, EU Member States are free to set their nationality law within their own discretion. This practice includes laws that significantly restrict the acquisition of nationality and laws that aggressively revoke nationality. For example, several Member States have exercised this discretion to refuse nationality to Roma/Romani people, ${ }^{2}$ or to certain Latvia "noncitizens," 3 or revoke nationality from individuals who have joined

1. See Ian Brownlie, Principles of Public International Law 394 (6th ed. 2003) ("Existing practice and jurisprudence does not support a general rule that deprivation of nationality is illegal").

2. See Adam M. Warnke, Vagabonds, Tinkers, and Travelers: Statelessness Among the East European Roma, 7 IND. J. GLOBAL L. STUD. 335, 361 (1999).

3. See Dimitry Kochenov \& Aleksejs Dimitrovs, EU Citizenship for Latvian “Noncitizens": A Concrete Proposal, 38 Houston J. INT'L L. 55, 55-56 (2016). 
the Islamic State of Iraq and Syria ("ISIS"). ${ }^{4}$ The practice of acquiring EU citizenship, being linked to the acquisition of Member State nationality, has largely tolerated these consequential limitations on acquiring EU citizenship.

However, international and European law continues to develop and increasingly constrains state freedom in adopting domestic nationality law. Regarding the revocation of Member State nationality, EU law demands that the state consider the possibly disproportionate consequential loss of EU citizenship. European human rights law limits revocation for the impact that act has on other human rights, such as freedom from discrimination and the right to one's identity. International law also restricts revocation of nationality when it results in statelessness or constitutes an arbitrary or discriminatory act. Regarding the refusal of Member State nationality acquisition, the same sources also constrain state freedom. EU law and European human rights law demand that such a refusal should not otherwise infringe other human rights, and international law obliges states to protect every person's right to a nationality. In many ways, both international and European law now make some revocations or refusals of nationality unlawful.

If a denial of Member State nationality is indeed unlawful, then the next question is whether such an unlawful act can have consequences for EU citizenship. Under both international law and European law, there are several remedies for an unlawful act. For example, EU Member States must act in line with the duty of sincere cooperation. Under international law, unlawful acts cannot create legal rights. This article will argue that, when the denial of Member State nationality is unlawful, other Member States and the Union itself may nonetheless recognize EU citizenship.

4. See Megan Specia, ISIS Cases Raise a Question: What Does It Mean to Be Stateless?, N.Y. TiMES (Feb. 22, 2019), https://www.nytimes.com/2019/02/22/world/middleeast/isisshamima-begum-citizenship-stateless.html [https://perma.cc/2V6D-GGRP] (reporting on the denationalization of Shamima Begum by the United Kingdom); Joseph Nasr, Susan Fenton, \& Ed Osmond, Germany to Strip IS Fighters of Citizenship, REUTERS (March 3, 2019), https://www.reuters.com/article/us-germany-justice-idUSKCN1QK0OH [https://perma.cc/5Q7N-VG5S]. See Shamima Begum v Sec'y St. Home Dep't, Appl. No. SC/163/2019, Open Judgment (Spec. Immigr. Appls. Comm'n, UK, Feb. 7, 2020). 


\section{ACQUISITION OF EU CITIZENSHIP}

EU citizenship was created by the Treaty on European Union. ${ }^{5}$ It is additional to and does not replace nationality. ${ }^{6}$ It provides a number of rights for the individual directly from EU law, but more than merely a description of various rights under European law, ${ }^{7}$ EU citizenship has come to be understood as the fundamental status of a person when exercising rights under European law. ${ }^{8}$ The acquisition of EU

5. See Consolidated Version of the Treaty on European Union art. 9, Oct. 26, 2012, O.J. (C 326/13) ("Every national of a Member State shall be a citizen of the Union. Citizenship of the Union shall be additional to and not replace national citizenship") [hereinafter TEU]; Consolidated Version of the Treaty on the Functioning of the European Union art. 20(1), Oct. 26, 2012, O.J. (C 326/47) [hereinafter TFEU], previously Consolidated Version of the Treaty on European Union \& Treaty Establishing the European Community art. 17, Dec. 24, 2002, O.J. (C $325 / 01$ ) ("Citizenship of the Union is hereby established. Every person holding the nationality of a Member State shall be a citizen of the Union. Citizenship of the Union shall be additional to and not replace national citizenship") [hereinafter TEC]; Directive 2004/38/EC, of the European Parliament and of the Council of 29 Apr. 2004 on the right of citizens of the Union and their family members to move and reside freely within the territory of the Member States, O.J. (L 158/78).

6. See TEU, supra note 5, art. 9.

7. See Case C-224/98, D'Hoop v. Office national de l'emploi, 2002 E.C.R. I-6221.

8. See Directive 2004/38/EC, of the European Parliament and of the Council of 29 Apr. 2004 on the right of citizens of the Union and their family members to move and reside freely within the territory of the Member States, O.J. (L 158/78) 3, supra note 5; Case C-221/17, Tjebbes et al. v. Minister van Buitenlandse Zaken, 2019 E.C.R. 4 (Mar. 12) [hereinafter Tjebbes Case]; Case C-82/16, K.A. \& Others, 2018 E.C.R. 47; Case C-165/14, Marín v. Admin del Estado, 2016 E.C.R. 107; Case C-304/14, Sec'y of State for the Home Dep't v. CS, 2016 E.C.R. 3; Case C-359/13, Martens v. Minister van Onderwijs, Cultuur en Wetenschap, 2015 E.C.R. 3; Case C-523/11, 585/11, Prinz v. Region Hannover \& Seeberger v. Studentenwerk Heidelberg, 2013 E.C.R. 3; Case C-256/11, Dereci et al v. Bundesministerium für Inneres, 2011 E.C.R. 62; Case C-135/08, Rottmann v. Bayern, 2010 E.C.R. 43; Case C-50/06, Comm'n Eur. Cmtys. v. Netherlands, 2007 E.C.R. 32; Case C-192/05, Tas-Hagen \& Tas v. Raadskamer WUBO van de Pensioen- en Uitkeringsraad, 2006 E.C.R. 18; Case C-145/04, Spain v. U.K., 2006 E.C.R. 74; Case C-209/03, Bidar v. Ealing, Sec'y State Educ. and Skills, 2005 E.C.R. 31; Case C-147/03, Comm'n Eur. Cmtys. v. Austria, 2005 E.C.R. 45; Case C-403/03, Schempp v. Finanzamt München v, 2005 E.C.R. 15; Case C-224/02, Pusa v. Osuuspankkien Keskinäinen Vakuutusyhtiö, 2004 E.C.R. 16; Case C-200/02, Zhu \& Chen v. Sec'y State Home Dep't, 2004 E.C.R. 25; Case C-482/01, 493/01, Orfanopoulos v. Baden-Württemberg v. Oliveri, 2004 E.C.R. 65; Case C-148/02, Avello v. Belgium, 2003 E.C.R. 22; Case C-413/99, Baumbast \& R v. Sec'y State Home Dep't, 2002 E.C.R. 82; Case C-224/98, D'Hoop v. Office national de l'emploi, 2002 E.C.R. 28; Case C-184/99, Grzelczyk v. Centre public d'aide sociale d'Ottignies-Louvain-laNeuve, 2001 E.C.R. 31; Case C-274/96, Criminal proceeding against Bickel \& Franz, 1998 E.C.R. I-7660; Case C-85/96, Martínez Sala v. Bayern, 1998 E.C.R. 59; Case C-53/81, Levin v. Staatssecretaris van Justitie, 1982 E.C.R. 1039. 
citizenship, is more than simply rights, it is also creating a status of a direct legal bond between the individual and the Union. ${ }^{9}$

Notwithstanding its nature as a fundamental, independent status, ${ }^{10}$ it does have some degree of dependency on the nationality of an EU Member State. ${ }^{11}$ This dependency, however, is limited to the acquisition of EU citizenship status. ${ }^{12}$ An individual acquires EU citizenship when he or she is "holding" the nationality of an EU Member State. ${ }^{13}$ EU law does not expressly state whether loss of EU citizenship status is also dependent on loss of member state nationality. ${ }^{14}$ By implication, it could be understood that loss is also dependent, though this has never been expressly confirmed.

Because the acquisition of EU citizenship is dependent on the acquisition of member state nationality, Member States can exercise a certain amount of discretion over whether an individual acquires it. ${ }^{15}$ Not only do Member States have a considerable degree of flexibility in prescribing their nationality laws, ${ }^{16}$ but Member States can also determine which individuals are considered its nationals for purposes of EU citizenship. ${ }^{17}$ This latter concern is primarily an issue of persons

9. See William Thomas Worster, Brexit and the International Law Prohibitions on the Loss of EU Citizenship, 15 INT'L ORG. L. REV. 341, 341 (2018).

10. See Dimitry Kochenov, Ius Tractum of Many Faces: European Citizenship and the Difficult Relationship Between Status and Rights, 15 CoLuM. J. EUR. L. 169, 181 n.81 (2009).

11. See Case C-165/14, Marín v. Admin del Estado, supra note 8, at 6; Case C-304/14, Sec'y State Home Dep't v. CS, supra note 8, at 3; Case C-135/08, Rottmann v. Bayern, supra note 8 , at 3; Worster, Brexit, supra note 9, at 352.

12. See Worster, Brexit, supra note 9 , at 354 .

13. See TFEU, supra note 5, at art. 20 ("Every person holding the nationality of a member States shall be a citizen of the Union").

14. See Worster, Brexit, supra note 9 , at 354 .

15. See Council Decision, concerning certain problems raised by Denmark on the Treaty of European Union, Denmark and the Treaty on European Union, annex 1, 1992 O.J. (C 348/01) 1; Case C-369/90, Micheletti \& Ors v. Delegación del Gobierno en Cantabria, 1992 E.C.R. I4258, I-4262; Report from the Commission on the Citizenship of the Union, COM (1993) 702 final (Dec. 21, 1993) 2 ("wherever in the Treaty establishing the European Community reference is made to nationals of the Member States, the question whether an individual possesses the nationality of a Member State shall be settled solely by reference to the national law of the Member State concerned.") [hereinafter Micheletti Case]; Third Report from the Commission on Citizenship of the Union, COM (2001) 506 final (Sept. 7 2001) 7 ("It is therefore worth pointing out that: - it is for each Member State to lay down the conditions for acquiring and losing the nationality of that state").

16. See Rottmann v Bayern, supra note 8; Case C-192/99, The Queen v Sec'y St. Home Dep't ex parte Kaur, 2001 E.C.R. I-1252, I-1259 [hereinafter Kaur Case].

17. Final Act to Treaty on European Union, Declaration on Nationality of a Member State, July 29, 1992, O.J. (C 191) 98. However, it is not entirely clear how much discretion Member 
connected to overseas territories who might have a slightly different legal relationship to the metropolitan state within the state's constitutional order. ${ }^{18}$ For example, Denmark has excluded the Faroe Islands from the European Union, even though the islands are part of the Kingdom of Denmark, and thus Faroe Islanders do not acquire EU citizenship. ${ }^{19}$ Similarly, the United Kingdom has identified certain forms and categories of nationality under domestic law that do not qualify for EU citizenship, even though the individual has some sort of legal bond with that state. ${ }^{20}$

\section{LAWFULNESS OF REFUSING OR REVOKING NATIONALITY}

The next section will discuss situations where revocation or refusal to grant nationality is unlawful. International law largely leaves states to implement their nationality laws in their own discretion and does not interfere. For example, the 1930 Hague Convention on Certain Questions Relating to the Conflict of Nationality Laws provides that "[i]t is for each State to determine under its own law who are its nationals" and that "[a]ny question as to whether a person possesses the nationality of a particular State shall be determined in accordance with

States have in this regard, see e.g. Akos G. Toth, The Legal Status of the Declarations Attached to the Single European Act, 23 COMMON MKT L. REV. 803, 807-12 (1986), although practice suggests it is quite expansive.

18. See TFEU, supra note 5, at art. 355(5); see also Treaty amending, with regard to Greenland, the Treaties establishing the European Communities art. 3, Feb. 1, 1985, O.J. (L 29); TEC, supra note 5, at arts. 182, 299(2)-(3), annex II; Reg 1612/68/EEC, of the Council of 15 Oct. 1968 on freedom of movement for workers within the Community, 1968 J.O. (L 257) 2; Case C-300/04, Eman \& Sevinger v. Coll. van Burgemeester en Wethouders van Den Haag, 2006 E.C.R. I-8060, I-8087.

19. See TFEU, supra note 5, art. 355(5)(a).

20. See TFEU, supra note 5, art. 355(5)(c); Note to the Government of the Italian Republic Concerning a Declaration Replacing the Declaration on the Definition of the Term 'National' Made at the Time of Signature of the Treaty of Accession of 22 Jan. 1972, 31 Dec. 1982, UKTS 67 (1983). The United Kingdom excluded certain EU citizenship rights from UK nationals in Jersey, Guernsey, and Man who are EU citizens, but do not have the right to free movement. This was only possible because the exclusion was included in the EU treaties and those persons never acquired the rights in the first place. It would be quite a different matter for the United Kingdom to attempt to revoke those rights. See also Treaty of Accession to the European Communities of the Kingdom of Denmark, Ireland, and the United Kingdom of Great Britain and Northern Ireland, 1st U.K. Declaration, Jan. 22, 1972, 1972 O.J. L 73/ 196; K.R. Simmonds, The British Nationality Act 1981 and the Definition of the Term "National" for Community Purposes, 21 COMMON MKT. L. REV. 675, 676-78 (1984). 
the law of the State." ${ }^{21}$ However, prior to the 1930 Hague Convention, the Permanent Court of International Justice had already opined that it was certainly possible for international law to govern the rules of nationality, and such limitations might arise in the future. ${ }^{22}$ Thus by 1955, the International Court of Justice ("ICJ") concluded that, where there was no genuine connection between an individual and the state, other states were not required to recognize the grant of nationality, ${ }^{23}$ already providing one exception to the more absolute rule stated in the Hague Convention. Later, the International Law Commission concluded that limitations imposed by international law were well established. ${ }^{24}$ What had not so clearly appeared in international law at this point was any obligation to grant nationality. That would come later. This section will consider the most recent developments in international law governing nationality, under both general international law and EU law, and apply to cases of revocation or refusal to grant nationality, in order to identify situations that may be unlawful.

\section{A. Revocation of nationality}

The first scenario of possible unlawful refusal of nationality contemplated in this article is the revocation of nationality. Historically, many states have claimed a right to revoke nationality and send former nationals into exile. ${ }^{25}$ As recently as 10 years ago, this

21. See, e.g., Hague Convention Governing Certain Questions Relating to the Conflict of Nationalities arts. 1-2, Apr. 12, 1930, 179 L.N.T.S. 89.

22. See Permanent Court of Int'1 Just. (ser. B) Advisory Opinion No. 4, at 24 (Feb. 7, 1923).

23. See Nottebohm Case (Liech. v. Guat.), Judgment, 1955 I.C.J. 4, at 23 (Apr. 6).

24. See Int'l Law Comm'n, Rep. on the Work of Its Fifty-Eighth Session, U.N. Doc. A/61/10, at 33-34 (2006) (states must comply with international law when granting their nationality); Report of the Commission to the General Assembly on the Work of its Fifty-First Session, (1999) (Vol. II)(2) Y.B. Int'1 L. Comm'n 24, U.N. Doc. A/CN.4/SER.A/1999/Add.1 (same); Documents of the Forty-Ninth Session, (1997) (Vol. II)(1) Y.B. Int'l L. Comm'n 20, U.N. Doc. A/CN.4/SER.A/1997/Add.1 (same, specifically regarding human rights law).

25. See Alien Act of 1793, 33 Geo. 3, c. 4 (UK) (does not distinguish between aliens and nationals); Penal Servitude Act of 1857, 20 \& 21 Vict., c. 2 (UK) (abolishing transportation); Charles Delessert, L'Etablissement et le Sejour des Etrangers au Point de Vu JuRIDIQUe ET PolitiQue 52 (1924); H. LESSING, DAS RECHT DER STAATSANGEHÖRIGKEIT UND DUE ABERKENNUNG DER STAATSANGEHÖRIGKEIT ZU STRAF-UND SICHERUNGSZWECKEN 113 (1937); Ernest Lehr, La Nationalité, in ERNEST LEHR, LES PRINCIPAUX ETATS DU GLOBE 16 (1909); Gerald R. Miller, Banishment-A Medieval Tactic in Modern Criminal Law, 5 UTAH L. REV. 365, 365-66 (1957). 
practice had all but ended, ${ }^{26}$ partly reflecting a revulsion against practices resembling the Nazi Nuremberg Laws. ${ }^{27}$ With the rise in global terrorism, a number of countries have reasserted the right to denationalize nationals who commit or provide aid to terrorist organizations, or are considering adopting provisions to revoke nationality. ${ }^{28}$ Within the European Union, Belgium, ${ }^{29}$ Denmark, ${ }^{30}$

26. See Chama L.C. Mubanga-Chipoya, Econ. \& Soc. Council, (Special Rapporteur), Analysis of the Current Trends and Developments Regarding the Right to Leave Any Country Including One's Own, and to Return to One's Own Country, and Some Other Rights or Considerations Arising Therefrom, U.N. Doc. No. E/CN.4/Sub. 2/1988/35, paras. 48, 116, 119 (June 20, 1988).

27. See Gefek Uber Den Miberrui Von Ginburderungen Und Die Ubbertunnung Der Deitinchen Graatsangehorigeit [Law Concerning Cancellation of Naturalizations and Deprivation of Nationality], July 14, 1933, RGBL. I at 480 (Ger.) (revoking naturalizations, primarily targeting Jews, between Nov. 9, 1918, and Jan. 30, 1933); JEAN-MARIE HENCKAERTS, MASS EXPULSION IN MODERN INT'L L. \& PRAC. 88-89 (1995); Megan Specia, ISIS Cases Raise a Question: What Does It Mean to Be Stateless?, N.Y. TIMES (Feb. 22, 2019), https://www.nytimes.com/2019/02/22/world/middleeast/isis-shamima-begum-citizenshipstateless.html [https://perma.cc/JB23-73GH].

28. See, e.g., Australia: R. Thwaites, New Laws Make Loss of Citizenship a CounterTerrorism Tool, THE CONVERSATION (Dec. 11, 2015), http://theconversation.com/new-lawsmake-loss-of-citizenship-a-counter-terrorism-tool-51725 [https://perma.cc/7XF7-NY9W]; Fact Check: How Does Australia's Plan to Strip Foreign Rights of Citizenship Compare to Other Nations?, ABC NEwS (June 11, 2015), http://www.abc.net.au/news/2015-0611/foreignfighters-citizenship-around-the-world/6498920 [https://perma.cc/B6NJ-9Q66]; An Act to Amend the Citizenship Act and to Make Consequential Amendments to Other Acts, c. 22 (Bill C-24) (Can.); Daiva Stasiulis, The Extraordinary Statelessness of Deepan Budlakoti: The Erosion of Canadian Citizenship Through Citizenship Deprivation, 11 STUD. IN SOC. JUST. 1, 8 (2017); Simon Tomlinson, Norway Considers Revoking Citizenship of People Who Take Part in Terror Activities or Wars Abroad - Echoing the Call of Boris Johnson, DAILY MAIL (Aug. 27, 2014), https://www.dailymail.co.uk/news/article-2735498/Norway-considers-revokingcitizenship-people-terror-activities-wars-abroad-echoing-call-Boris-Johnson.html [https://perma.cc/2SGP-5LFG].

29. See Code PÉnAl [C.Pén.] [Belgian Criminal Code], art. 23/2 (Belg.); Grounds for Concern: Belgium's Counterterror Responses to the Paris and Brussels Attacks, HuM. RTS. WATCH (Nov. 3, 2016, 7:32 AM), https://www.hrw.org/report/2016/11/03/groundsconcern/belgiums-counterterror-responses-paris-and-brussels-attacks\#page [https://perma.cc/2N42-AV3W].

30. See Straffeloven [Danish Crim. Code], § 114 (Den.). 
France, ${ }^{31}$ the Netherlands, ${ }^{32}$ and the United Kingdom, ${ }^{33}$ have adopted provisions to revoke nationality when a national commits a terrorism offense. Other EU states, such as Germany and Sweden, have also considered similar measures. ${ }^{34}$ This section will first examine whether such practices would violate EU law, and secondly, whether they would violate international law.

\section{European regional law}

The Court of Justice of the European Union ("CJEU”) has ruled directly on point that revocation of nationality by a member state of the European Union may implicate EU law. In the Rottmann case, the Court found that when a member state withdraws its nationality from an individual, it must take into consideration the impact on EU citizenship, ${ }^{35}$ and, in the Tjebbes case, the Court held that this consideration must be an individualized assessment, not an automatic operation of law. ${ }^{36}$ While the CJEU fundamentally respected the power of the member state to withdraw nationality, it suggested that a Member

31. See Kim Willsher, Hollande Drops Plan to Revoke Citizenship of Dual-National Terrorists, GUARDIAN (Mar. 30, 2016), https:/www.theguardian.com/world/2016/mar/30/francois-hollande-drops-plan-to-revokecitizenship-of-dual-national-terrorists [https://perma.cc/D75W-TNNY] (considering, and rejecting, even more expansive denationalization measures for dual nationals from birth); Maïa de la Baume, Court Upholds France's Move to Strip Citizenship of Man Jailed on Terror Charge, N.Y. TIMES (Jan. 23, https://www.nytimes.com/2015/01/24/world/europe/amedy-coulibaly-paris-attacks-burial.html [https://perma.cc/2VLU-UFTN] (only applying to naturalized nationals).

32. See Rijkswet op het Nederlanderschap [Netherlands Nationality Act], art. 14(2) (Neth.); see also Tjebbes Case, supra note 8.

33. See Victoria Parsons, The Bureau of Investigative Journalism, Theresa May deprived 33 Individuals of British Citizenship in 2015 (June 21, 2016), https://www.thebureauinvestigates.com/stories/2016-06-21/citizenship-stripping-new-figuresreveal-theresa-may-has-deprived-33-individuals-of-british-citizenship [https://perma.cc/M7VL-P9AR].

34. See, e.g., Germany Plans to Strip Passports of Fighters with 2nd Nationality, AL JAZEERA (Mar 4, 2019), https://www.aljazeera.com/news/2019/03/germany-plans-strippassports-fighters-2nd-nationality-190304182914343.html [https://perma.cc/J5ST-268K]; Justin Huggler, Dual Nationals Who Fight for Terror Groups to be Stripped of German Citizenship, Telegraph (Aug. 11, 2016); Arthur Lyons, Swedish Prime Minister Refuses to Strip Citizenship: "ISIS Fighters Can Return," VOICE EUR. (Mar. 5, 2019), https://voiceofeurope.com/2019/03/swedish-prime-minister-refuses-to-strip-citizenship-isisfighters-can-return/ [https://perma.cc/T3CP-N953].

35. See Rottmannn v. Bayern, supra note 8.

36. See Tjebbes Case, supra note 8, paras. 9-10. 
State was not entirely free to act as it wished in regards to domestic nationality law. ${ }^{37}$

What remains still unclear from Rottmann and Tjebbes is whether the Court would ever find a withdrawal of nationality so significant for EU citizenship that it would find the withdrawal unlawful. We might consider, for example, a case of withdrawal of nationality as the direct result of the exercise of EU citizenship rights, such as a withdrawal of nationality due to extended time resident abroad relying on the right to free movement. ${ }^{38}$ It is difficult to see how such a revocation would be lawful under EU law, though it does stretch Rottmann and Tjebbes quite far. Surely the CJEU would not permit a state to revoke an individual's nationality when he or she simply exercised their rights under EU law. Another more difficult scenario might be revocation of nationality as punishment for the distasteful exercise of free speech or some other fundamental right. Again, it seems wrong at first glance, though identifying the precise legal basis is more challenging. Unfortunately, the CJEU has not given us more guidance on whether acts would ever rise to the level that the court would adjudge the act a violation of EU law, and, in fact, Tjebbes suggests that this bar is quite high.

One other important implication comes out of Rottmann and Tjebbes for EU citizenship: they reaffirm that EU citizenship is a separate and independent status from member state nationality. If EU citizenship was entirely dependent on and derivative from member state nationality, then EU citizenship should not be a distinct issue from the withdrawal of member state nationality. It should not call for a separate consideration under EU law. Since the CJEU concluded that these cases do call for a distinct consideration as to EU citizenship, then we must conclude that the Court conceives of EU citizenship as having its own distinct rights and nature. ${ }^{39}$ Of course, this judgment only

37. See Dimitry Kochenov, A Real European Citizenship: A New Jurisdiction Test: A Novel Chapter in the Development of the Union in Europe, 18 COLuM. J. EuR. L. 55, 77 (2011).

38. See Case C-221/17, Tjebbes Case, supra note 8 (explicitly excluding such a scenario from consideration, though implying that such a scenario would raise significantly distinct considerations); Dimitry Kochenov, supra note 10, at 191 (citing Nicholas Sitaropoulos, Freedom of Movement and the Right to a Nationality v. Ethnic Minorities: The Case of ex Art. 19 of the Greek Nationality Code, 6 EuR. J. Migration \& L. 205, 205 (2004).

39. See Dimitry Kochenov, supra note 37, at 76; see generally Worster, Brexit, supra note 9 (2018) (arguing that Brexit revocation of EU citizenship without revocation of Member State nationality is problematic). 
reaffirms the view on the independence of EU citizenship that was expressed in the earlier cases. ${ }^{40}$

We should probably not make too big a point of emphasizing that EU law protects EU citizenship, because the Court of Justice in Rottmann and Tjebbes only emphasized that the Member State must take EU law into consideration. In the actual aftermath of Rottmann, Germany reacted to the Court's judgment by affirming Rottmann's loss of nationality, following consideration of the impact on EU citizenship. ${ }^{41}$ In Tjebbes, the Court ordered an individualized assessment, though it upheld the right of the Netherlands to revoke nationality due to the mere failure to renew a passport. ${ }^{42}$ And it is unclear what criteria any individualized consideration would need to include and evaluate. ${ }^{43}$ The EU legal protection of EU citizenship seems to be quite weak.

In any event, it appears that EU law does have some notional limitation, albeit vague and persuasive, on the ability of Member States to withdraw their nationality with consequences for EU citizenship. While we do not yet know the precise parameters of those limitations from EU law, ${ }^{44}$ it is certainly conceivable that an abusive, punitive, perhaps arbitrary, revocation of nationality, with consequences for EU citizenship, might run afoul of EU law. To date no Member State has ever attempted to withdraw member state nationality without also withdrawing EU citizenship. Perhaps those legal gymnastics will come in time, ${ }^{45}$ although if the individual still retained EU citizenship, then

40. See Micheletti Case, supra note 15 (refusing to permit a Member State to apply its own nationality laws, following Nottebohm's genuine link, to an individual holding nationalities of both a Member State and a non-Member State); Nottebohm Case, supra note 23, at 23; see also Zhu \& Chen v. Sec'y of State for the Home Dep't, supra note 8; Case C-136/78, Ministère Public v. Vincent Auer, E.C.R. 1979 450. Cf. Case C-34/09, Zambrano v. Office national de l'emploi, E.C.R. 2011 I-1251 (although not discussing the interference with enjoyment of EU citizenship, the Court held a similar standard for interference with the enjoyment of EU citizenship rights).

41. Bundesverwaltungsgericht [BVerwGE] [Supreme Administrative Court], Nov. 11, 2010, 5 C 12.10 (F.R.G.).

42. See Tjebbes Case, supra note 8, para. 44.

43. See id.

44. See Andrew C. Evans, Nationality Law and the Free Movement of Persons in the EEC: With Special Reference to the British Nationality Act 1981, 2 Y.B. EUR. L. 173, 189 (1982) (arguing duty of loyalty limits discretion).

45. Note that this idea is not entirely excluded. A provision to make it impossible to sever Member State nationality and EU citizenship was proposed and rejected. See Draft Treaty Establishing the European Union 1984 O.J. (C 77) art. 3 ("The citizens of the Member States 
it will be difficult for the member state to resist giving the individual admission and residence.

In addition, to EU law protecting EU citizenship, EU law also protects other rights that may be implicated by a withdrawal of nationality. The EU legal order includes the Charter of Fundamental Rights as a binding obligation. ${ }^{46} \mathrm{By}$ its terms, the charter does not explicitly protect a right to nationality or EU citizenship. However, it does prohibit EU Member States from imposing measures based on "any discrimination," including race, ethnicity, social origin, genetic features, and others. ${ }^{47}$ While it has not been adjudicated on point, there is no good reason to believe that this provision would not apply to nationality legislation. Following on the argument above, it should not be lawful for an EU Member State to revoke nationality as a consequence of the exercise of Charter rights, or revoke nationality that might have an unjustified impact on the enjoyment of Charter rights.

The above paragraphs discussed EU law and while the European Convention of Human Rights ("ECHR") is not an EU instrument, the protections within the Convention are binding on their own before the European Court of Human Rights ("ECtHR") and are relevant in interpreting protections of EU law under the Charter of Fundamental Rights. The Convention does not expressly protect the right to acquire or retain a nationality. ${ }^{48}$ The one exception to this failure to intervene in nationality matters is Protocol No. 4 to the ECHR which prohibits states from withdrawing nationality merely as a pretext to expulsion. ${ }^{49}$ However, the revocation of nationality can be reviewed by the ECtHR

shall ipso facto be citizens of the Union. Citizenship of the Union shall be dependent upon citizenship of a Member State; it may not be independently acquired or forfeited.").

46. See Charter of Fundamental Rights of the European Union, O.J. (C 364) 1 (Dec. 18, 2000).

47. See id. at art. 21.

48. See Makuc v. Slovn., Appl. No. 26828/06, Partial Decision as to the Admissibility, para. 160, Eur. Ct. H. R., 3d Sec., (May 31, 2007); Poenaru v. Rom., Appl. No. 51864/99, Decision as to the Admissibility, Eur. Ct. H. R., (Nov. 13, 2001); Karassev v. Finland, App. No. 31414/96, Decision (Final) as to the Admissibility, Eur. Ct. H. R., 4th Sec., (Jan. 12, 1999); Family K. \& W. v. Neth., App. No. 11278/84, Decision. at 216 Eur Comm'n H. R., July 1, 1985; X. v. Aust., App. No. 5212/71 Eur. Comm'n H. R., Oct. 5, 1972.

49. See Protocol No. 4 to the [European] Convention for the Protection of Human Rights and Fundamental Freedoms, Securing Certain Rights and Freedoms Other Than Those Already Included in the Convention and in the First Protocol thereto, Sep. 16, 1963, Eur. Treaty Series 4; Explanatory Report to Protocol No. 4, para. 23. 
when it impacts other rights that are in the convention, ${ }^{50}$ for example, Article 8 , the right to private and family life. ${ }^{51}$ The Court analyzes a violation of Article 8 by examining whether the nationality revocation was arbitrary and the consequences of the revocation. ${ }^{52}$ Arbitrariness is tested by whether the measure is provided in law, ${ }^{53}$ and whether there are procedural safeguards, both the possibility of judicial review ${ }^{54}$ and diligent action by the authorities. ${ }^{55}$ As a consequence, the ECtHR considers whether the individual is rendered stateless. ${ }^{56}$ Following these criteria, the Court has in the past found nationality revocation to have been permissible, ${ }^{57}$ although cases may arise in the future that will constitute a violation of Article 8. Other claims for violations have included Article 13 (right to an effective remedy), and Article 4 of Protocol No. 7 (ne bis in idem). ${ }^{58}$

In addition to the ECHR, another convention under the auspices of the Council of Europe governs nationality issues: the European Convention on Nationality (ECN). ${ }^{59}$ It provides that everyone has a right to a nationality. ${ }^{60}$ Unfortunately it does not widespread adherence, but if a member state who was party to the Convention withdrew

50. See Karassev v. Finland, supra note 48; Kafkasli v. Turk., Appl. No. 21106/92, Judgment (1995); Salahddin Galip v. Greece, Appl. No. 17309/90, Judgment (1995).

51. See K2 v U.K., Appl. No. 42387/13, Decision. on the Admissibility, para. 49 (2017); Ramadan v. Malta, Appl. No. 76136/12, Judgment, para. 85 (2016); Genovese v. Malta, Appl. No. 53124/09, paras. 30, Eur. Ct. H. R., (Oct. 11, 2011); Savoia \& Bounegru v. It., App. No. 8407/05, Decision (2006); Slivenko v. Lat., App. No. 48321/99, Decision, para. 77 (2002); Karassev v. Finland, supra note 48.

52. See K2 v. U.K., supra note 51.

53. See id. para. 50.

54. See id. at para. 55 .

55. See id. at para. 50; Ramadan v. Malta, supra note 51, paras. 86-89.

56. See K2 v. U.K., supra note 51, para. 62.

57. See id.

58. See Protocol No. 7 to the [European] Convention for the Protection of Human Rights and Fundamental Freedoms, Securing Certain Rights and Freedoms Other Than Those Already Included in the Convention and in the First Protocol Thereto, Sep. 16, 1963, Eur. Treaty Series 117; Council of Eur., Parliamentary. Assembly, Resolution 2263 (2019) (Prov. ver.); Withdrawing Nationality as a Measure to Combat Terrorism: a Human Rights-Compatible Approach?, http://assembly.coe.int/nw/xml/XRef/Xref-XML2HTML-EN.asp?fileid=25430 [https://perma.cc/L9MJ-ALWQ]; see also Council of Eur., Parliamentary Assembly, Committee on Legal Aff. and Hum. Rts, Tineke Strik, Rapporteur, Report, Doc. 14790, Withdrawing Nationality as a Measure to Combat Terrorism: A Human Rights-Compatible Approach? (2019), http://assembly.coe.int/nw/xml/XRef/Xref-DocDetailsen.asp?FileID=25241\&lang=en [https://perma.cc/SND5-N68W].

59. See European Convention on Nationality, Nov. 6, 1997, E.T.S. 166.

60. See id. 
nationality contrary to its terms, then that withdrawal would be unlawful, for example, if revocation of nationality was only permitted for naturalized citizens. ${ }^{61}$

\section{International law}

International law also imposes some limitations on the ability of a state to revoke nationality. These limitations fall into several broad categories of statelessness, arbitrariness, and other miscellaneous obligations. International law, of course, binds the EU Member States. However, the European Commission has argued that, part of having due regard to Union law means having "due regard" to international law, ${ }^{62}$ suggesting that compliance with international law on nationality was additionally obliged by EU law.

\section{a. Statelessness}

Statelessness obligations primarily arise under treaty law. ${ }^{63}$ States that are party to the 1961 Statelessness Convention are under an obligation to prevent statelessness and reduce the number of cases of

61. See id. art. 5.2; Council of Eur. Parliamentary Assembly, Resolution. 2263 (2019) (Prov. ver.), Withdrawing Nationality as a Measure to Combat Terrorism: a Human RightsCompatible Approach?, available at http://assembly.coe.int/nw/xml/XRef/Xref-XML2HTMLEN.asp?fileid=25430 [https://perma.cc/ZA47-E447].

62. See Case C-4/73, Nold Kohlen-und Baustoffgrobhandlung v. KG Comm'n Eur. Comm'ties, 1974 E.C.R. 492; Case C-181/73 Haegeman v Belgium, 1974 E.C.R. 450, para. 5; Case C-104/81 Kupferberg v. Hauptzollamt Mainz, 1982 E.C.R. 3644, para. 12; Case C-286/90, Anklagemindigheden v. Poulsen \& Diva Navigation, 1992 E.C.R. I-6048, paras. 9-10; Case C162/96, Racke v. Hauptzollamt Mainz, 1998 E.C.R. I-3688, paras. 45-46; Case C-308/06, Queen on the App. of Int'l Assoc. of Indep. Taker Owners (Intertanko), et al. v. Sec'y St. Trans., Judgment, 2008 E.C.R., para. 38; Rottmannn v Bayern, supra note 8, paras. 28-29; Case C366/10, Air Transp. Assoc. Am. And Ors v Sec'y St. Energy \& Climate Change, 2011 E.C.R. I13833, paras. 73, 101 [hereinafter Air Transp. Case]; European Commission, Report from the Commission to the European Parliament, the Council, the Eur. Econ. and Soc. Committee and the Committee of the Regions, at 5, COM (2019) 12 final (2019) ("Having due regard to EU law means taking into account all rules forming part of the Union legal order and includes having due regard to norms and customs under international law as such norms and customs form part of EU law").

63. See Convention on the Reduction of Statelessness art. 8, Aug. 30, 1961, 989 U.N.T.S. 175 (hereinafter 1961 Statelessness Convention). Certainly this limitation applies to states party to the 1961 Statelessness Convention, but might also apply to states generally under customary international law. This author has argued elsewhere that such a rule applies under customary international law, but that argument will be omitted here because it is not necessary for the conclusions herein however, on this point see European Court of Human Rights, Kuric \& Ors v. Slovenia, App. No. 26828/06, Eur. Ct. H. R. (2010). 
statelessness. ${ }^{64}$ As of 2019 , EU Member States that are party to the 1961 Statelessness Convention include Austria, Belgium, Bulgaria, Croatia, Czech Republic, Denmark, Finland, France, Germany, Hungary, Ireland, Italy, Latvia, Lithuania, the Netherlands, Portugal, Romania, Slovakia, Spain, Sweden, and the United Kingdom, constituting the majority of the Member States. In addition, the European Union has itself pledged that all the states in the Union would adhere to the 1961 Statelessness Convention in the future, ${ }^{65}$ and the CJEU has stated that the creation of statelessness by withdrawing nationality would not be a legitimate revocation of Member State nationality. ${ }^{66}$

There are a few exceptions to the prohibition on creating stateless. Necessarily, individuals with multiple nationalities may have their nationality removed without a violation of the statelessness rule. ${ }^{67}$ The convention itself provides that stateless may nonetheless be created in situations of (1) residence abroad seven or more years without declaration of intent to retain nationality; ${ }^{68}$ (2) taking up residence in the state for at least one year after attaining majority age, when born abroad; ${ }^{69}(3)$ fraud or misrepresentation in naturalization process; ${ }^{70}$ and (4) situations where the state has entered a reservation to the treaties for cases of loyalty, oaths, or services to foreign states, or acts "seriously prejudicial to the vital interests of the State."71

64. See 1961 Statelessness Convention, supra note 63, arts. 7(3), 8(1); see also Convention on Certain Questions Relating to the Conflict of Nat'lity Laws, Apr. 12, 1930, League of Nations Doc. C.224.M.111.1930.V (1930); League of Nations, Protocol Relating to a Certain Case of Statelessness, 12 April 1930, No. 4138. 179 L.N.T.S 115; Special Protocol Concerning Statelessness, League of Nations Doc. C.227.M.114, 1930 V (not yet entered into force).

65. See Council of the European Union, Conclusions of the Council and the Representatives of the Governments of the Member States on Statelessness (Dec. 4, 2015), https://www.refworld.org/docid/5829c53a4.html [https://perma.cc/manage/create].

66. See, Tjebbes Case, supra note 8, para. 37. But see Rottmannn v. Bayern, supra note 8 (where the revocation of nationality would have rendered the applicant stateless).

67. See generally William Thomas Worster, International Law and the Expulsion of Individual with More than One Nationality, 14 UCLA J. INT'L L. \& FOR. AFF'RS 423 (2009).

68. See 1961 Statelessness Convention, supra note 63, arts. 7(4), 8(2)(a).

69. See id. para. 7(5), 8(2)(a).

70. See id. para. $8(2)(\mathrm{b})$.

71. See id. para. 8(3). 
Some EU Member States have taken advantage of this option and entered a reservation. For example, the United Kingdom communicated the following to the depositary: ${ }^{72}$

"[The UK declares that it] retains the right to deprive a naturalised person of his nationality on the following grounds ... that, inconsistently with his duty of loyalty to Her Britannic Majesty, the person (i) Has ... rendered or continued to render services to, or received or continued to receive emoluments from, another State, or (ii) Has conducted himself in a manner seriously prejudicial to the vital interests of Her Britannic Majesty."

Austria, Belgium, France, Ireland, Italy, Lithuania, and Spain have entered similar reservations, ${ }^{73}$ leaving only Bulgaria, Croatia, Czech Republic, Denmark, Finland, Germany, Hungary, Latvia, the Netherlands, Portugal, Romania, Slovakia, and Sweden without the exception (4) above, but still retaining exceptions (1) through (3).

All of the above means that an EU Member State may not, in principle, revoke the nationality of a person with only one nationality. The only exceptions would be when the individual has committed fraud in the naturalization process, has maintained extended residence aboard, or has never taken up residence in the state after being born abroad. In addition, Austria, Belgium, France, Ireland, Italy, Lithuania, Spain and the United Kingdom have the additional exception that they may also revoke nationality when the individual has acted in a manner that is "seriously prejudicial to the vital interests of the State."

\section{b. Arbitrary or discriminatory measures}

Beyond these treaty provisions expressly covering statelessness, a number of other human rights treaties, in fact most other human right treaties provide for a right to a nationality. ${ }^{75}$ These treaties however,

72. See U.N. Treaty Collection, Ch. V(4), Reservation Upon Ratification (Mar. 9, 1966), available at $\mathrm{https} / / /$ treaties.un.org/pages/ViewDetails.aspx? src=TREATY\&mtdsg_no=V4\&chapter=5\&lang=en\#EndDec [https://perma.cc/5FSX-LMAU].

73. See id.

74. See id. art. 3(a)(ii).

75. See Convention on Certain Questions Relating to the Conflict of Nationality Law art. 1, Apr. 13, 1930, 179 L.N.T.S 89; Protocol relating to a Certain Case of Statelessness, Apr. 12, 1930, 179 L.N.T.S 115; G.A. Res. 1040, Convention on the Nationality of Married Women, paras. 1-3 (Jan. 29, 1957) [hereinafter CNMW]; G.A. Res. 61/177, Int'l Convention for the Protection of All Persons from Enforced Disappearance, art. 25(4) (2007); Int'l Convention on the Elimination of All Forms of Racial Discrimination art. 5(d)(iii), Dec. 21, 1965, 660 U.N.T.S. 
contain several weaknesses, leaving states some discretion to revoke nationality lawfully. That being said, states are not completely free to revoke nationality when that revocation would be arbitrary.

The obligation to ensure that every person enjoys a nationality has two significant weaknesses. The first weakness is that it only requires that an individual have "a" nationality, but does not clearly identify the state that must extend nationality. ${ }^{76}$ However, for the instant question, when an individual has only one nationality, a state that revokes that nationality is creating a stateless person, and thus the state is clearly violating the individual's right to a nationality. Prior to the revocation the individual had a nationality, and following the revocation, the individual does not have a nationality, due to the deliberate action of the state.

The second weakness is that states may deprive individuals of their nationality under these human rights treaties, provided they do not act arbitrarily. ${ }^{77}$ The CJEU has recognized the restriction on arbitrary revocation of nationality as a "general principle of international law." 78 Arbitrariness has been interpreted as having two meanings: procedural arbitrariness and substantive arbitrariness. ${ }^{79}$ Procedural arbitrariness results from a state acting without a legal basis for doing so, ${ }^{80}$ or not

195 [hereinafter CERD]; International Covenant on Civil and Political Rights art. 24(3), Dec. 16, 1966, 999 U.N.T.S. 171 [hereinafter ICCPR]; Convention on the Elimination of All Forms of Discrimination against Women art. 9, Dec. 18, 1979, 1249 U.N.T.S. 13 [hereinafter CEDAW]; Int'l Convention on the Protection of the Rights of All Migrant Workers and Members of their Families art. 29, Dec. 18, 1990, 2220 U.N.T.S. 3 [hereinafter "CPMW"]; Convention on the Rights of the Child art. 7, Nov. 20, 1989, 1577 U.N.T.S. 3. Also see G.A. Res. 217 (III) A, Universal Declaration of Human Rights (1948) [hereinafter UDHR].

76. See ICCPR, supra note 75, art. 24(3) ("Every child has the right to acquire a nationality"); UDHR, supra note 75, art. 15(1).

77. See U.N. Secretary-General, Arbitrary Deprivation of Nationality: Report of the Secretary-General, para. 65, U.N. Doc. A/HRC/10/34 (Jan. 26, 2009) [hereinafter Arbitrary Deprivation of Nationality].

78. See Rottmannn v. Bayern, supra note 8.

79. See Baruch Ivcher Bronstein v. Peru, Case 11,762, Inter-Am. Comm'n on H.R., Report No. 20/98, OEA/Ser. L./V/II.95, doc. 5 rev para. 95 (2001); Arbitrary Deprivation of Nationality, supra note 73; Human Rights Council, UN Secretary-General \& UNHCHR, Arbitrary Deprivation of Nationality (Jan. 26, 2009), para. 61 et seq.; U.N. Secretary-General, Human Rights and Arbitrary Deprivation of Nationality, para. 40, U.N. Doc A/HRC/13/34 (Dec. 14, 2009) [hereinafter Arbitrary Deprivation Report 2009].

80. See Elettronica Sicula S.p.A. (“ELSI”) (U.S. v. It.), 1989 I.C.J. 15, para. 128 (July 20); see also Baruch Ivcher Bronstein v. Peru, Case 11.762, Inter-Am. Comm'n H.R., Report No. 20/98, OEA/Ser.L./V/II.95, doc. 5 rev para. 95 (2001); Eri. v. Eth., Claims Comm'n, Partial Award: Civilian Claims (Eri. v. Eth.), 44 I.L.M. 601, paras. 57-78 (Perm. Ct. Arb. 2004); 
providing for effective legal process. ${ }^{81}$ While this possibility may be implicated in cases of nationality revocation, it is not necessarily relevant, so we will not discuss it any further.

Substantive arbitrariness, however, is very relevant. Substantive arbitrariness is linked to the notion that laws must be proportionate to their legitimate objectives. ${ }^{82}$ For example, some actions are almost always considered substantively arbitrary, most importantly, discrimination on the basis of race, gender, religion, etc. ${ }^{83}$ Where revocation of nationality is motivated by discrimination on protected grounds, then the revocation will be unlawful. ${ }^{84}$ One ground of

Explanatory Report to the European Convention on Nationality, Council of Europe 166, 36 (1997) http://conventions.coe.int/Treaty/en/Reports/Html/166.htm [https://perma.cc/BH9A$\mathrm{HNCU}$ ] (providing that denaturalization "must in general be foreseeable, proportional and prescribed by law") [hereinafter Explanatory Report: Nationality].

81. See U.N., Hum. Rts. Committee, No 27: Article 12 (Freedom of Movement), U.N. Doc. CCPR/C/21/Rev.1/Add.9 (1999) [hereinafter "Freedom of Movement"]; U.N. SecretaryGeneral, Hum. Rts. and Arbitrary Deprivation of Nationality, paras. 43-46, U.N. Doc A/HRC/13/34 (Dec. 14, 2009); U.N. Secretary-General, Human Rts. and Arbitrary Deprivation of Nationality, para. 40, U.N. Doc A/HRC/25/28 (Dec. 19, 2013); Int'l L. Comm'n, Draft Articles on Nationality of Natural Persons in relation to the Succession of States, with commentaries, U.N. Doc A/54/10, at 38 (1999).

82. See ICCPR, supra note 71, art. 26; see also Elettronica Sicula S.p.A. ("ELSI") (U.S. v. It.), 1989 I.C.J. 15, para. 128 (July 20); Asylum Case (Colom. v. Peru), Judgment, 1950 I.C.J. 284 ("Arbitrariness is not so much something opposed to a rule of law, as something opposed to the rule of law"); Freedom of Movement, supra note 81, para. 21; Van Alphen v. Neth., Hum. Rts. Comm., No. 305/1988, U.N. Doc. CCPR/C/39/D/305/1988, 5 (1990); A v Aust'lia, Hum. Rts. Comm., No 560/1993, UN Doc CCPR/C/59/D/560/1993, 9 (1997); Stewart v. Can., Hum. Rts. Comm., No. 538/1993, U.N. Doc. CCPR/C/58/D/538/1993 (1996), (Evatt \& Medina Quiroga, Indiv. Op.; Aguilar Urbina, Dissent, para. 8); Eri. v. Eth., Claims Comm'n, Partial Award: Civilian Claims (Eri. v. Eth.), 44 I.L.M. 601 (Perm. Ct. Arb. 2004), 44 I.L.M 601 (Eri. Award), paras. 57-78.

83. See Convention on the Reduction of Statelessness, supra note 65, art. 9; CERD, supra note 75; CEDAW supra note 71, art. 9(1); G.A. Res., Draft International Declaration of Human Rights, E/800, UN Doc A/C.3/SR.123, 352 (Nov. 5, 1948) (Eleanor Roosevelt: "individuals should not be subjected to action such as was taken during the Nazi regime in Germany when thousands had been stripped of their nationality by arbitrary government action"); G.A. Res. 10/13 para. 2-3 (March 26, 2009); H.R.C. Res. 20/5, U.N. Doc A/HRC/RES/20/5, at 2-4 (July 16, 2012); H.R.C. Res.7/10, U.N. Doc A/HRC/RES/20/5, at 2-3; International Law Commission, Draft Articles Nationality in relation to the Succession of States, art. 15 (prohibiting discrimination "on any ground").

84. See UDHR, supra note 75, art. 15(2); CEDAW, supra note 75, art. 9; CERD, supra note 75, art. 5(d)(iii); Convention on the Rights of Persons with Disabilities art. 18, G.A. Res. 61/106, 76th plen. mtg., U.N. Doc A/RES/61/106 (Dec. 13, 2006) [hereinafter CRPD]; see also European Convention on Nationality, supra note 76, arts. 3(2), 5(1); Karassev v. Finland, supra note 48; Inst. for Hum. Rts. \& Dev. in Africa ("IHRDA") and Open Soc. Just. Initiative on Behalf of Children of Nubian Descent in Kenya v. The Gov't of Kenya. No. Com/002/2009, 
prohibited discrimination is specifically important in this case and that is discrimination between nationals based on whether they acquired their nationality by birth or by subsequent naturalization. ${ }^{85}$

Other cases not involving prohibited discrimination are tested for proportionality, meaning that the objective of the revocation must be legitimate and the measures taken must be tailored to the objective. The Human Rights Council, UN Secretary-General and UN High Commissioner for Refugees ("UNHCR") have concluded that that revocation of nationality resulting in statelessness is necessarily substantively arbitrary. ${ }^{86}$ Setting aside the creation of statelessness, other views help inform us of when revocation would be proportionate. The Human Rights Committee has concluded in General Comment No. 27 that states may not revoke nationality merely as a means to expel a person and that there are "few, if any, circumstances in which deprivation of the right to enter one's own country could be reasonable." 87 The ECN takes a slightly more liberal position, suggesting which cases might fall in this limited exception, by providing for several cases that will not be considered substantively arbitrary. Those cases are limited to: voluntary acquisition of another nationality; acquisition of the nationality by fraud or deception; voluntary service in a foreign military force; conduct seriously prejudicial to the vital interests of the state; lack of a genuine link

African Committee of Experts on the Rts. and Welfare of the Child, para. 57 (March 22, 2011); Case of Girls Yean \& Bosico v. Dom. Rep., Reparations and Costs, Judgment, Inter-Am. Ct. H.R. (ser. C) paras. 136, 139, 141 (Sept. 8, 2005); Expelled Dominicans \& Haitians v. Dom. Rep., Reparations and Costs, Judgment, Inter-Am. Ct. H.R. (ser. C) para. 263 (Aug. 28, 2014); H.R. Council, Draft Report of the Working Group on the Universal Periodic Review: Myanmar, paras. 7.54, 7.55, 7.66, U.N. Doc. A/HRC/WG.6/23/L.9 (Nov. 10, 2015) [hereinafter Myanmar Report]; H.R. Council, Draft Report of the Working Group on the Universal Periodic Review: Austria, paras. 5.4, 5.5, U.N. Doc. A/HRC/WG.6/23/L.20 (Nov. 11, 2015) [hereinafter Austria Report]; Hum. Rts and Arbitrary Deprivation of nationality: report of the Secretary-General, U.N. Doc. A/HRC/13/34, art. 4 (Dec. 14, 2009); Dimitry Kochenov, EU Influence on the Citizenship Policies of the Candidate Countries: The Case of the Roma Exclusion in the Czech Republic, 3 J. CONTEMP. EUR. RES. 124 (2007).

85. See Withdrawing Nationality as a Measure to Combat Terrorism: A Human RightsCompatible Approach EUR., PARL. ASS., RES. 2263 (2019); see also Withdrawing Nationality as a Measure to Combat Terrorism: a Human Rights-Compatible Approach?, EuR., PARL. AsS. Doc. 14790 (2019).

86. See 1961 Statelessness Convention, supra note 63, art. 8; Arbitrary Deprivation Report 2009, supra note 79; European Convention on Nationality, supra note 59, art. 7(3).

87. Hum. Rts. Comm., General Comment No. 27, Freedom of Movement, U.N. Doc. CCPR/C/21/Rev.1/Add.9 (1999). 
between the state and a national habitually residing abroad; or failure of a child to fulfill preconditions established by law. ${ }^{88}$ All other grounds are unreasonable. The Ethiopia-Eritrea Claims Commission agreed with this approach in part when it held that withdrawal of nationality was proportionate in cases where when the person presents a serious security risk or holds another nationality. ${ }^{89}$

\section{c. Other issues}

In addition to the major issues of statelessness and the right to a nationality, there are several other obligations that states may violate when they revoke nationality, rending the revocation unlawful. Two examples will be briefly mentioned here: rights of the child and obligations for international criminal justice.

First, all Member States of the European Union are parties to the Convention on the Rights of the Child ("CRC"). The Convention requires states to consider the best interests of the child in all decisions pertaining to children, ${ }^{90}$ and especially for those rights enumerated in the $\mathrm{CRC}$, specifically, such as the right to a nationality. If a state proposes to revoke a child's nationality, either alone or in conjunction with the revocation of the parent's nationality, that decision must be motivated by being in the best interests of the child. ${ }^{91}$ However, numerous bodies have expressed the view that becoming stateless is never in the best interests of a child. ${ }^{92}$ The only way to overcome this obligation would be a very strong showing that having the nationality of an EU Member State (and potentially having EU citizenship) was not in the child's interests, and it is difficult to understand how a child would be better off with that result.

\footnotetext{
88. See European Convention on Nationality, supra note 59, arts. 5(1), 7(3).

89. See Eri. v. Eth., supra note 76, at paras. 57-78.

90. See Convention on the Rights of the Child, Sep. 2, 19901577 U.N.T.S. 3, art. 3 [hereinafter CRC].

91. See U.N. Secretary-General, Status of the Convention of the Rights of the Child, U.N. Doc. A/68/257 (Aug. 2, 2013), para. 57 et seq.

92. See CRC, supra note 90, art. 3; Hum. Rts. Comm., Gen. Comm. 17, para. 8, U.N. Doc. HRI/GEN/1/Rev.1 (1989); CRC, Comm. Rts. Child, UN Doc. CRC/C/CZE/CO/3-4 (Aug 4, 2011); U.N.H.C.R., Guidelines on Statelessness, No. 4, para. 11, HCR/GS/12/04 (Dec. 21, 2012); U.N. Secretary-General, Human Rights and Arbitrary Deprivation of Nationality, art. 4, U.N. Doc. A/HRC/25/28 (Dec.13, 2013) [hereinafter Arbitrary Deprivation Report 2013]; Ofc. High Comm'r Hum. Rts., The Rights of the Child, Fact Sheet No.10 (Rev.1) (1997). Afr. Comm. Children, Gen. Comm. 2, ACERWC/GC/02 (Apr. 16, 2014) ("being stateless as a child is generally an antithesis to the best interests of children").
} 
Secondly, abolishing the link of nationality may violate the Member State's obligations to cooperate in prosecuting international crimes. All EU Member States are parties to the Rome Statute of the International Criminal Court ("ICC"). The Court acquires complementary jurisdiction over individuals who they either commit crimes within the territories of states parties to the Rome Statute or simply have the nationality of a state party to the Rome Statute and commit crimes anywhere. ${ }^{93}$ Setting aside crimes that are committed in states parties, it may be that the only way that the Court has jurisdiction over certain persons is due to them holding the nationality of an EU Member State. If that nationality is withdrawn, then the Court's jurisdiction is abolished. The Rome Statute obliges states to exercise criminal jurisdiction over individuals responsible for international crimes when they have it, ${ }^{94}$ and to cooperate with the ICC in investigation and prosecution. ${ }^{95}$ It is certainly arguable that by withdrawing the nationality of nationals who may have committed international crimes (e.g. through association with ISIS), the EU Member State is terminating the jurisdiction of the ICC over these persons, and not cooperating with the potential prosecution of persons by the Court. ${ }^{96}$ Similarly, the UN Security Council in Resolution 2178 has ordered all states to cooperate in combating terrorism, including exercising controls over their nationals. By revoking nationality, the Member State would be unilaterally renouncing its ability to exercise certain controls, and, again, might be refusing to cooperate with the

93. See Rome Statute of the International Criminal Court art. 12, July 17, 1998, 2187 U.N.T.S. 90, U.N. Doc. A/CONF.183/9 ("2. In the case of article 13, paragraph (a) or (c), the Court may exercise its jurisdiction if one or more of the following States are Parties to this Statute or have accepted the jurisdiction of the Court in accordance with paragraph 3: (a) The State on the territory of which the conduct in question occurred ... (b) The State of which the person accused of the crime is a national") [hereinafter Rome Statute].

94. See id. at preamble ("The States Parties to this Statute, ... Recalling that it is the duty of every State to exercise its criminal jurisdiction over those responsible for international crimes ...").

95. See id. art. 86, ("States Parties shall, in accordance with the provisions of this Statute, cooperate fully with the Court in its investigation and prosecution of crimes within the jurisdiction of the Court").

96. The EU Member States would still retain jurisdiction over the person and crimes, should the person appear in the state's jurisdiction, under the concept of universal jurisdiction for war crimes, crimes against humanity and genocide. But by terminating nationality, the claim of active nationality jurisdiction by the state is also foregone. 
Security Council's order. Certainly the Council of Europe believes this to be the case. ${ }^{97}$

\section{B. Refusal of nationality}

Having discussed the possibilities when the revocation of nationality would be unlawful, we now turn to the unlawful refusal to grant nationality. In some ways the refusal to grant nationality is a harder case to make as an unlawful act. After all, revocation of nationality brings up a sense of loss of acquired rights, whereas refusal to grant nationality denies the person from acquiring more rights. At first glance, states appear to have rather unfettered discretion in determining who acquires their nationality as an inherent aspect of sovereignty. Certainly, they appear to have considerable freedom in establishing which kinds of links are sufficient to create the necessary bond between the individual and the state. While that distinction between loss and acquisition of nationality is important, in some ways refusal to grant nationality is perhaps better protected, at least for certain situations, such as children born stateless. We will examine these situations under European regional law and general international law.

\section{European regional law}

EU law imposes some protections from revocation of nationality on Member States, but it is significantly less protective in cases of refusal of nationality. Quite simply, without acquiring nationality, and thus EU citizenship, EU law does not apply. While EU law on the protection from refusal of EU citizenship is less demanding than in cases of revocation, the Charter rights do still apply to all persons in the European Union, regardless of nationality. As such, EU Member States should not be able to refuse nationality where this refusal is

97. See U.N.S.C. Res. 2178 (Sept. 24, 2014); Resolution Withdrawing Nationality as a Measure to Combat Terrorism: A Human Rights-Compatible Approach, EUR. PARL. DOC. No. 2263 (2019), available at http://assembly.coe.int/nw/xml/XRef/Xref-XML2HTMLEN.asp?fileid=25430 [https://perma.cc/2YTD-SWQ3]; see also Council of Europe, Tineke Rapp, Rapporteur, Report, Withdrawing Nationality as a Measure to Combat Terrorism: a Human Rights-Compatible Approach?, Doc. $14790 \quad$ (2019) available at $\mathrm{http} / / /$ assembly.coe.int/nw/xml/XRef/Xref-XML2HTML-EN.asp?fileid=25430 [https://perma.cc/F7BH-B4XL]. 
imposed as a consequence of the exercise of Charter rights or where the refusal would impact Charter rights.

Similarly, the ECtHR has ruled that the refusal to grant nationality can impact the enjoyment of rights under the ECHR. As noted above, the ECHR does not provide for a right to acquire a nationality. ${ }^{98}$ Once again, claims of that nature need to be articulated instead as claims for violations of other rights under the Convention, for example, the refusal of nationality might amount to a degrading treatment, contrary to Article 3. ${ }^{99}$ One difficulty is that it is unclear whether refusal of nationality can amount to an infringement of rights in the ECHR. For example, a claim under whether refusal of nationality can amount to an Article 6 (right to a fair trial) regarding the failure of the national authority to process a naturalization application was not successful. ${ }^{100}$ Also unsuccessful was a claim that the refusal of nationality infringed the right to private life. ${ }^{101}$

However, one situation where refusal of nationality has been found to amount to an ECHR violation is when refusal violates the right to social identity. In Mennonson, France refused to grant nationality to children conceived through in vitro fertilization (IVF), because such practice was contrary to French law. The Court disagreed that refusal of nationality was the correct result for children conceived through IVF. While it is within the authority of the French State to prohibit IVF, it was a violation of the right to social identity to refuse nationality to children born of French parents as a result. ${ }^{102}$ Similarly, the Court found that it was a violation of the right to social identity to refuse nationality in cases of state succession, where the individual should

98. See Makuc v. Slovn., supra note 48; Poenaru v. Rom., supra note 48; Karassev v. Finland, supra note 48; Family K. \& W. v. Neths, supra note 48; X. v. Austria, Appl. No. 5212/71 Eur. Comm'n Human Rts., (Oct. 5, 1972).

99. See Slepcik v. Neth. \& Czech Rep., Appl. No. 30913/96, Eur. Comm'n, Hum Rts., (September 2, 1996) (referring to E. Afr. Asians v. UK., Appl. Nos. 4403-19/70, 4422-23/70, 4434/70, 4443/70, 4476-78/70, 4486/70, 4501/70, 4526-30/70, Eur. Comm'n, Hum Rts., (Dec. 14, 1973); Zeibek v Gr., Appl. No. 34372/97, Eur. Comm'n, Hum Rts., (May 21, 1997).

100. See Laura van Waas, Fighting Statelessness and Discriminatory Nationality Laws in Europe, 14 EUR. J. MigRATION \& L. 243-60 (2014).

101. See Family K \& W v. Neths., supra note 48 ("the right to acquire particular nationality is neither covered by, nor sufficiently relate to, [article 8 in conjunction with article $14]$ or any other provision of the convention").

102. See Genovese v. Malta, supra note 51, paras. 30-33; Mennesson v. Fr., Appl. No. 65192/11), Eur. Ct. Hum. Rts (June 26, 2014); Labassee v. Fr., Appl. No. 65941/11, Eur. Ct. Hum. Rts (June 26, 2014). 
have acquired the nationality of the new state, now sovereign over the area of the person's habitual residence. ${ }^{103}$

One important consideration that makes the violation especially compelling is whether the refusal of nationality concerns a child who is born in the state and would be otherwise stateless. At least in a dissenting opinion, Judge Pinto de Albuquerque argued that the ECHR obliges states to grant nationality to children born in their territories who would otherwise be stateless. ${ }^{104}$ While this view on protection under the ECHR might still be a minority opinion, the ECN expressly protects the acquisition of nationality specifically. In the ECN, everyone is granted a right to a nationality, which means, inter alia, that states must grant nationality to a child at birth when either parent is a national and a child is born in the state or where the child would be otherwise stateless. ${ }^{105}$ A similar provision is made in cases of state succession in the Convention on the Avoidance of Statelessness in relation to State Succession. ${ }^{106}$ Thus, if a Member State is a party to the $\mathrm{ECN}$, then the protection against nationality refusal leading to statelessness is more certain than if the Member State is only party to the ECHR.

\section{International law}

In the section above, discussing the revocation of nationality, we already discussed a number of arguments where international law protected a person's nationality. The primary two protections are the protection against statelessness and the protection of a right to "a" nationality (i.e., non-arbitrary revocation). However, the refusal to grant a nationality is a slightly different scenario than revocation. When

103. See Fedorova v. Latvia, Appl. No. 69405/01, Dec., Eur. Ct. H. R., (Oct. 9, 2003).

104. See Ramadan v. Malta, supra note 51, paras. 86-89; Kuric \& Others v. Slovenia, Appl. No. 26828/06, Eur. Ct. Hum. Rts, (July 13, 2010).

105. See European Convention on Nationality, supra note 59, art. 6; Arbitrary Deprivation Report 2013, supra note 92, art. 4.

106. See Convention on the Avoidance of Statelessness in Relation to State Succession art. 10, May 19, 2006, Eur. Treaty Series No. 200; Eur. Comm'n for Democracy through Law at its 28th Plenary Meeting, Venice Commission Declaration on the Consequences of State Succession for the Nationality of Natural Persons: Declaration on the Consequences of State Succession for the Nationality of Natural Persons, 13-14 (Sept. 1996); Council of Europe, Convention on the Avoidance of Statelessness in Relation to State Succession, Explanatory Report, art. 2, available at http://www.conventions.coe.int/Treaty/EN/Reports/Html/200.htm [https://perma.cc/54BC-DXXJ]. 
it comes to the grant of nationality, this act is usually based on one of two situations: birth or naturalization. Although a few other highly unusual options also exist, this paper will focus only on birth or naturalization. Similar concerns exist for refusal of nationality as did for revocation of nationality, when it pertains to the rights of the child and the child's best interests. ${ }^{107}$ However, in this section, we will focus on the refusal of nationality at birth and by naturalization.

\section{a. Nationality at birth}

The protection against statelessness coves the refusal to grant nationality at birth. ${ }^{108}$ Recall that the 1961 Statelessness Convention prohibited denationalization of a person unless the grounds fell within a short list of permissible reasons for the revocation. However, none of the exceptions apply to the refusal of acquisition of nationality at birth; they all address the revocation of nationality already acquired.

International law will oblige a state to grant nationality in the rare situation that a child would be stateless. This Author has written previously that, under customary international law, we must interpret the right to a nationality, ${ }^{109}$ and the protections against statelessness, to mean that a child born in a state will receive the nationality of that state if the child would otherwise be stateless. ${ }^{110}$ This author reaffirms this finding, but for purposes of this Article, we will not explore that line of argument further.

Treaty law also imposes a similar obligation as customary international law, though only where the EU Member States are parties to the treaties. The 1961 Statelessness Convention commands that a

107. See infra Sec. III.A.2.iii; see generally William Thomas Worster, The Obligation to Grant Nationality to Stateless Children Under Customary International Law, 27 MiCH. ST. INT'L L. REV. 441 (2019).

108. See 1961 Statelessness Convention, supra note 63, art. 8. Certainly this limitation applies to states party to the 1961 Statelessness Convention, but might also apply to states generally under customary international law. This Author has argued elsewhere that such a rule applies under customary international law, see, e.g., William Thomas Worster, The Obligation to Grant Nationality to Stateless Children Under Customary International Law, 27 MiCH. ST. INT'L L. REV. 441 (2019), but that argument will be omitted here because it is not necessary for the conclusions herein, however, on this point compare the positive view of the European Court of Human Rights, Kuric and Others v. Slovenia, Appl. No. 26828/06, (Eur. Ct. Hum. Rts July 13, 2010).

109. See UDHR, supra note 75, art. 15(1); ICCPR, supra note 75, art. 24(3); CRC, supra note 90 art. 7; CERD, supra note 75, art. 5(d)(iii); CPMW, supra note 75, art. 29.

110. See generally Worster, supra note 107. 
state grant nationality to stateless children born in the state's territory, without exception. The right to a nationality under other human rights treaties does not explicitly provide for the state of birth to grant nationality to an otherwise stateless child, although they may be interpreted to impose that obligation. Various bodies have agreed that the right against arbitrary revocation of nationality also applies equally to arbitrary refusal. ${ }^{111}$ After all, when a child is born stateless, he or she is within the jurisdiction of only one state at the time of birth. There is only one state that may bear the obligation for the child to have "a" nationality. This conclusion is an exception to the general rule that we cannot usually identify the state that is obliged to secure the right to a nationality. Thus, the state where the stateless child is born must ensure that the child has a nationality, which could be by granting nationality or securing the child's nationality from another state. For this reason, a state would act unlawfully if it refuses to grant a newly born child its nationality, unless the state effectively secures the child's nationality from another state. So if a child effectively held another nationality at birth, then the birth state is excused from ranting its nationality. ${ }^{112}$

In addition, other human rights may be relevant. For example, a refusal to grant nationality that is discriminatory on one of the protected grounds, ${ }^{113}$ or results as punishment for the exercise of other human rights, will be problematic. Also, refusals to recognize the nationality of persons habitually resident in the territory of a new state would be problematic if they resulted in statelessness. ${ }^{114}$

111. See 1961 Statelessness Convention, supra note 63, art. 1(1); ICCPR, supra note 75, art. 24(3); CPMW, supra note 75, art. 29; CRC, supra note 90, art. 7(1), (1990); Arbitrary Deprivation Report 2009, supra note 79, para. 60 ("In the context of the avoidance of statelessness, arbitrary denial of nationality is just as grave as arbitrary deprivation of nationality"); see generally U.N. Secretary-General, Impact of the Arbitrary Deprivation of Nationality on the Enjoyment of the rights of Children Concerned, and Existing Laws and Practices on Accessibility for Children to Acquire Nationality, inter alia, of the Country in Which They are Born, if They Otherwise Would be Stateless, U.N. Doc. A/HRC/31/29 (Dec. 16, 2015) [hereinafter Arbitrary Deprivation Report 2015]; Office High Comm'r Refugees, Exec. Comm. Concl. No. 106 (LVII) (2006), para. (i); H.R.C. Gen. Comm. 17, para. 8.

112. See Karassev v. Finland, supra note 48.

113. See CERD, supra note 75, art. 5(d)(iii); CEDAW, supra note 75, art. 9; CRPD, supra note 84, art. 18; Arbitrary Deprivation Report 2009, supra note 79, art. 4, U.N. Doc. A/HRC/13/34 (Dec.14, 2009); Myanmar Report, supra note 84, paras. 7.54, 7.55, 7.66; Austria Report, supra note 84, paras. 5.4, 5.5.

114. See Human Rights Council Res. 32/5, U.N. Doc. A/62/53 (June 30, 2016) (“6. Encourages States to grant their nationality to persons who had habitual residence in their 


\section{b. Naturalization}

The refusal to extend nationality to a person in the naturalization process is the other scenario for refusal of nationality. Naturalization is a significantly different scenario from acquisition at birth. ${ }^{115}$ In naturalization, the state granting nationality often has considerably more discretion in deciding which persons qualify for nationality. At the outset, we should note that naturalization policies that discriminate on the impermissible bases of race, color, gender, religion, political opinion or national or ethnic origin, are highly suspect and most likely unlawful under international law. ${ }^{116}$ However, a state still retains broad authority to determine qualification, even setting aside the discriminatory grounds. In addition, although other instruments encourage naturalization, but do not necessarily mandate it. For example, the Refugee Convention obliges states to facilitate the naturalization of refugees. ${ }^{117}$ There are a few situations in which a state is expected to naturalize individuals.

Under EU law, states have not had their discretion limited over laws providing for naturalization. ${ }^{118}$ In the Kaur case, the CJEU held

territory before it was affected by the succession of States, especially if those persons would otherwise become stateless").

115. See UDHR, supra note 75, art. 15(1); CNMW, supra note 75, arts. 1-3; ICCPR, supra note 75, art. 24(3); CERD, supra note 75, art. 5(d)(iii); CEDAW, supra note 75, at art. 9; CPMW, supra note 75, art. 29; CRPD, supra note 84, art. 18(1)-(1); H.R.C. Dec. 2/111 (27 Nov. 2006); H.R.C. Res. 13/2; H.R.C. Res. 10/13; H.R.C. Res. 7/10; H. R. Comm'n Res.1998/48 (17 Apr. 1998); H.R.C. Res. 1999/28; H.R.C. Res. 2005/45 (19 Apr. 2005); H.R.C. Gen. Comm. 17, paras. 7-8; H.R.C. Res. 2005/45; CEDAW Gen. Recomm. No. 21: Equality in Marriage and Family Relations, 1994, art. 9.

116. See ICCPR, supra note 75, art. 24(3); CEDAW, supra note 75, art. 9; CRC, supra note 90, arts. 7, 8; CRPD, supra note 84, art. 18 Comm. on the Elimination of Racial Discrimination, General Recommendation XXX on Discrimination Against Non-Citizens (Oct. 1, 2002) [hereinafter Discrimination Recommendation 2002]; Hum Rts. Comm. Gen Recomm. No. 24.

117. See Convention relating to the Status of Refugees art. 34, July 28, 1951, 189 U.N.T.S. 137; Protocol Relating to the Status of Refugees, Jan. 31, 1967, 606 U.N.T.S. 267 ("[Parties] shall as far as possible facilitate the assimilation and naturalization of refugees. They shall in particular make every effort to expedite naturalization proceedings and to reduce as far as possible the charges and costs of such proceedings").

118. See Rottmann v. Bayern, supra note 8; Kaur Case, supra note 16; Micheletti Case, supra note 15; Eur. Council Dec. concerning certain problems raised by Denmark on the Treaty of European Union, Annex 3, section A 'Citizenship', Denmark and the Treaty on European Union, Dec. 31, 1992, O.J. (C 348) 1; First Report on the Citizenship of the Union, EUR. PARL. DOC. (COM 702) (1993) ("wherever in the Treaty establishing the European Community reference is made to nationals of the Member States, the question whether an individual 
that a refusal by the United Kingdom to naturalize an application did not raise issues under EU law. ${ }^{119}$ The reasoning in that case is that, prior to the naturalization, the individual does not hold EU citizenship, so the protections of EU citizenship have not accrued to the person. It is a highly formalistic approach that does not engage with the problem of the Member State acting as a gatekeeper to EU citizenship.

One possible argument is the duty of sincere cooperation among EU Member States. ${ }^{120}$ Recently the European Commission has produced a report criticizing the practice of some Member States that grant expedited nationality to wealthy investors, even without a residency or genuine connection requirement. ${ }^{121}$ These "citizenshipby-investment" schemes not only grant EU Member State nationality, but also, necessarily, EU citizenship. ${ }^{122}$ Usually it is the EU citizenship that is the prize, permitting the individual to take up unfettered residence in London, Paris, Amsterdam, Rome, or Berlin rather than Valletta or Nicosia. A particularly problematic aspect of the Member State granting nationality accrued the benefit of the individual's investment, but did not have to bear the burden of providing services to the new EU citizen who was resident in a more fashionable Member State.

The Commission suggests that the citizenship by investment schemes constitute an infringement of the duty of sincere cooperation through the application of naturalization law. The Commission cited the Nottebohm case ${ }^{123}$ for the notion that nationality should only be acquired on the basis of a "genuine connection" to the state. ${ }^{124}$

possesses the nationality of a Member State shall be settled solely by reference to the national law of the Member State concerned"); Third Report from the Commission on Citizenship of the Union, EUR. PARL. DOC. (COM 506) (2001); Fourth Report on Citizenship of the Union, EUR. PARL. DOC. (COM 695) (2004); Fifth Report on Citizenship of the Union, EUR. PARL. DoC. (COM 85) (2008).

119. See Kaur Case, supra note 16.

120. See TEU, supra note 5, art. 4(3).

121. See Investor Citizenship and Residence Schemes in the European Union, EUR. PARL. DoC. (COM 12) 22-23 (2019).

122. See id.

123. See Nottebohm Case, supra note 23.

124. The Commission also offered its interpretation of a qualifying "genuine connection" to include "genuine connection with the people of the country (by descent, origin or marriage) or on a genuine connection with the country, established either by birth in the country or by effective prior residence in the country for a meaningful duration. Other elements may be required to attest to the existence of a genuine bond with the country, such as knowledge of a 
However, the Commission additionally argued that, following Nottebohm, nationality granted by a state need only be recognized by other states where such genuine connection exists. It continued to argue that "[s]uch a common understanding of the bond of nationality [genuine connection under Nottebohm] also lies at the basis of Member States' acceptance that Union citizenship and the rights entailed by it under the Treaty on the Functioning of the European Union ("TFEU") would accrue automatically to any person becoming one of their citizens." 125 While this is a correct statement of Nottebohm, this argument is in direct conflict with Micheletti. Under Micheletti, the European Union has a lex specialis regime on recognition of nationality so that Member States are not permitted to second-guess the grant of Member State nationality or give priority to another nationality, because such practice would impact the enjoyment of EU citizenship. Strange enough, the Commission also cites to Micheletti in its report. 126 The conclusion of the Commission is that the only way for Member States to comply with Micheletti and yet also apply the Nottebohm criterion is for the Member State granting nationality to be obliged to apply Nottebohm. ${ }^{127}$ Thus, Member States should be required to apply the Nottebohm genuine link to their grants of nationality due to the duty of sincere cooperation under the Treaty on European Union ("TEU"). ${ }^{128}$

Following from this report's analysis, the duty of sincere cooperation, which requires EU Member States to apply international law to the acquisition of nationality, limits Member State discretion in granting nationality. While an individual might not have a claim against a Member State for refusal of nationality as per Kaur, the other Member States of the Union might have a claim under Article 4(3) of the TEU. However, it is yet unclear what the duty of sincere cooperation may require in terms of requiring the grant of nationality contrasted with

national language and/or of the culture of the country, links with the community." Investor Citizenship and Residence Schemes in the European Union, supra note 121, at 5.

125. See id. at 5.

126. See id. (citing Case C-369/90, Micheletti \& Others v Delegación del Gobierno en Cantabria 1992 E.C.R. I-4253).

127. See id. at 6 ("each Member State needs to ensure that nationality is not awarded absent any genuine link to the country or its citizens").

128. See id. at n.31 ("The principle of sincere cooperation with other Member States and the Union laid down by Article 4(3) TEU, obliges Member States to refrain from measures that could jeopardise the attainment of the Union's objectives"). 
obliging Member States to refuse the grant nationality. After all, the Commission cited the impact on EU citizenship in Rottmann (which concerned the revocation of Member State nationality) to support its conclusion on the impact of citizenship by investment schemes (concerning the grant of Member State nationality). ${ }^{129}$ Apparently, revocation of nationality and the grant of nationality are governed by the same principles of due regard for EU law. There may be a trend towards further erosion of Member State discretion in granting nationality through naturalization in the future.

\section{CONSEQUENCES OF THE UNLAWFUL DENIAL OF NATIONALITY}

The above sections detailed the many ways in which the revocation or refusal of EU Member State nationality might violate EU law or international law. This discussion did not attempt to be completely thorough and definitive, other than to simply highlight that the revocation or refusal of nationality can be unlawful. These protections vary from situation to situation with comparably stronger protection in the case of revocation to relatively weaker protection in the case of refusal. If a state refuses or revokes nationality in a way that violates one of these provisions above, then the next question is the impact on an individual's EU citizenship.

The initial step in this analysis is to identify which actor would be responsible for breaching international law by denying nationality. ${ }^{130}$ The EU Member State refusing or revoking nationality would surely be responsible since the norms described above are binding on states. ${ }^{131}$ But while the Member State has violated international law, that violation does not automatically result in reversing the decision in

129. See id. at 5 ("The Court of Justice of the EU has held, in what is now settled caselaw, that, while it is for each Member State to lay down the conditions for the acquisition and loss of nationality, they must do so having due regard to Union law"). See also Micheletti Case, supra note 15; Case C-179/98, Belg. v. Mesbah, 1999 E.C.R. I-07955; Case C-192/99, Kaur Case, supra note 16; Zhu \& Chen v. Secretary of State for the Home Dep't, supra note 8; Rottmann v. Bayern, supra note 8; Tjebbes Case, supra note 8.

130. See Int'l Law Comm'n, Rep.: Draft Articles on Responsibility of States for Internationally Wrongful Acts, with commentaries, U.N. Doc. A/56/10, art 2, (2001), [hereinafter Draft Articles on State Responsibility]; Int'l Law Comm'n, Rep: Draft Articles on the Responsibility of International Organizations, with commentaries, U.N. Doc. A/66/10, art. 4 (2011) [hereinafter Draft Articles on Responsibility of International Organizations].

131. See Draft articles on State Responsibility, supra note 130, art. 13. 
domestic law to deny nationality. Thus, EU citizenship would not necessarily be restored in the eyes of the Member State. The following paragraphs will examine the separate consideration of whether other EU Member States or the Union itself might also be responsible if they give recognition to the wrongful decision of the Member State.

To begin this analysis, we start with the obligation on all Member States to give effect to EU citizenship. The TFEU states that an individual has EU citizenship when he or she is "holding" the nationality of a Member State. ${ }^{132}$ Implicitly, "holding" is the exclusive way to acquire EU citizenship, not merely one method of many. ${ }^{133}$ However, the rule of "holding" as stated in the TFEU is not complete. As noted above, there are other ways that individuals can be excluded from EU citizenship despite "holding" Member State nationality. ${ }^{134}$ In addition, the provision does not state that EU citizenship is lost upon loss of the Member State nationality, nor does it clearly state that EU citizenship is lost upon the withdrawal of a Member State from the

132. See Treaty on the Functioning of the European Union, art. 20(1), Oct. 10, 2012, O.J. (C 326) 56. See also Directive 2004/38/EC, of the European Parliament and of the Council of 29 April 2004 on the Right of Citizens of the Union and Their Family Members to Move and Reside Freely Within the Territory of the Member States Amending Regulation (EEC) N0 1612/68 and Repealing Directives 64/221/EEC. Case C-413/99, Baumbast, supra note 8; Case C-224/98, D'Hoop v. Office National de l'emploi, 2002 E.C.R. I-06191.

133. See Worster, Brexit, supra note 9, at 359 (noting that a state joining the European Union, and becoming an EU Member State, is the one exception to the usual rule that a person only acquires EU citizenship when he or she acquires EU Member State nationality; in this case, the person acquires the nationality and EU citizenship at separate moments).

134. Cf. Treaty on the Functioning of the European Union (Consolidated Version), art. 355(5) (ex. art. 299(2), 1st sub-para. \& art 299(3)-(6) TEC), Oct. 10, 2012, O.J. (C 326) 198 ("the Treaties shall not apply to the Faeroe Islands") with Treaty amending, with regard to Greenland, the Treaties establishing the European Communities, 13 Mar. 1984, 1985 O.J. (L 29). See also Treaty on the Functioning of the European Union (Consolidated Version), art. 355(5)(c) (ex. art 299(2), 1st sub-par. \& art 299(3)-(6) TEC), Oct. 10, 2012, O.J. (C 326) 198 ("the Treaties shall apply to the Channel Islands and the Isle of Man only to the extent necessary to ensure the implementation of ... the European Economic Community and ... European Atomic Energy Community"); Note From the Government of the United Kingdom and Northern Ireland to the Government of the Italian Republic Concerning a Declaration by the Government of the United Kingdom of Great Britain and Northern Ireland Replacing the Declaration on the Definition of the Term "National" Made at the Time of Signature of the Treaty of Accession of January 22, 1972 by the United Kingdom of Great Britain and Northern Ireland to the European Communities, from R. Arculus, Her Majesty's Ambassador at Rome, to the Minister of Foreign Affairs of Italy (Dec. 31, 1982) U.K.T.S. 67 (1983) ("a) British citizens; b) Persons who are British subjects by virtue of Part IV of the British Nationality Act 1981 ...”); Treaty of Accession to the European Communities of the Kingdom of Denmark, Ireland, and the United Kingdom of Great Britain and Northern Ireland, 1st U.K. Declaration, Jan. 22, 1972, 1972 O.J. (L 73), 196. 
Union. ${ }^{135}$ Although this automatic loss of EU citizenship could be implied by the present tense of the verb "holding," and Rottmann seems to suggest that conclusion, the strong norms against loss of nationality in international law might argue against this assumption. ${ }^{136}$ Nonetheless, "holding" appears to be the, probably exclusive, test for the acquisition of EU citizenship, with other rules pertaining to exceptions to the "holding" rule.

"Holding" could have one of several meanings. Generally, it suggests a de facto grasping of nationality, yet we also frequently say that we can "hold" a claim of right despite not presently enjoying it in fact. By contrast, the TFEU does not say that a person has EU citizenship "upon confirmation of Member State nationality" or "upon production of a member State passport," or some similar phrase. ${ }^{137}$ Where a person has lost his or her passport or national identity card, he or she is still an EU citizen, though evidentiary issues may be challenging in such a case. We could even imagine a situation where a Member State acknowledged that the person holds its nationality, yet refuses to print a passport for some, possibly unlawful, reason. In these cases, we recognize that the person "holds" the right to nationality. The terms in the TFEU are phrased not as a de facto enjoyment or evidencing of nationality, but as a consequential operation of law. Thus, we should more correctly understand the term "holding" to mean that if a person holds Member State nationality by right of law, then he or she holds EU citizenship, also by right of law.

In addition, the TFEU should be interpreted consistent with international law, including, inter alia, the rules on interpreting treaties ${ }^{138}$ and the rules on responsibility, ${ }^{139}$ but also primary rules such as the right to a nationality. This is not to say that international law overrules the TFEU, but that, when ambiguous, the treaty should be

135. See Worster, Brexit, supra note 9, at 341. Equally it does not state that EU citizenship is acquired when a state joins the EU. Again, that effect is deduced from the language in the TEU. See id.

136. See id.

137. See supra note 132. 331.

138. See Vienna Convention on the Law of Treaties art. 31, May 23, 1969, 1155 U.N.T.S.

139. See Draft Articles on the Responsibility of International Organizations, supra note 125, at 53, art. 4. See generally THE INTERNATIONAL RESPONSIBILITY OF THE EUROPEAN UNION: EUROPEAN AND INTERNATIONAL PERSPECTIVES (Malcom Evans \& Panos Koutrakos eds., 2013). 
read in compliance with international law. While EU citizenship is not a nationality in the sense of being a legal bond with a state, it is a legal bond with the Union, and international law protections on nationality focus on the legal bond as the status that is being protected. ${ }^{140}$ After all, the Member State could have used any number of different terms in the Treaties on European Union than "citizenship" to describe this status, and yet they deliberately choose to use it. Like nationality, citizenship is also necessarily a status expressing a legal bond with a state. If the Union can contemplate a "citizenship," then it should have sufficient capacity to contemplate a legal bond. Mutatis mutandis, international law should protect EU citizenship in a similar manner as protection of nationality. If international law would prohibit states from refusing nationality, then the terms in the TFEU should be read that way as well.

This possibility to independently inquire into whether a person holds Member State nationality, and thus EU citizenship, should be distinguished from Micheletti. In that case, the CJEU held that when nationality was granted, other Member States cannot refuse to recognize it. ${ }^{141}$ Here, the question is where nationality was refused, whether other Member States must recognize that refusal. In a sense, the receiving Member State is refusing to recognize an act of state of the other Member State, but surely the receiving Member State is not prohibited from taking a more generous view in favor of the person.

Having considered that the TFEU can be interpreted to permit a receiving Member State to recognize nationality, even when the original Member State is denying nationality, we next consider whether a refusal to consider the person an EU citizen would be unlawful. The other Member States of the Union could be faced with a person whose nationality has been revoked or refused by one of the sister states in the European Union. The Member State receiving the person will need to determine how to address the situation if the individual claims that this denial is wrongful, and if he or she actually enjoys EU citizenship and rights such as free movement. While the initial denial of nationality would be unlawful, the receiving state will have to take separate decisions in reaction to the unlawful act. For example, the receiving Member State would have to decide if the person was an EU citizen for purposes of admission and expulsion, rights to remain and seek employment, voting in certain elections, and so on. Because these are

140. See Worster, Brexit, supra note 9 at 357.

141. See Micheletti Case, supra note 15, para. 15. 
distinct acts, and the TFEU would permit a state to interpret "holding" liberally, a Member State recognizing an unlawful denial of nationality would be committing its own distinct unlawful act.

A similar analysis applies to the Union itself. Of course, EU law applies to the Union, but the other obligations under international law mentioned in the previous sections also apply. ${ }^{142}$ The Union, as a separate legal person, will see that its Member States disagree over the nationality of an individual, with one outcome favoring EU citizenship and the other not. If the issue comes before the Union, perhaps by referring the case to the CJEU or if the individual is a candidate for European Parliamentary election or applies for an employment position with the organs of the Union, ${ }^{143}$ the Union will need to determine whether the person enjoys EU citizenship. The reasoning above suggests that an individual appearing in a Member State, claiming nationality in another Member State and EU citizenship, but whose original Member State refuses to acknowledge nationality, might nonetheless "hold" nationality sufficient for EU citizenship. If a Member State refuses to recognize that EU citizenship that the person holds by right, then the Member State would have violated European law.

\section{A. Obligation of cessation}

The following sections will examine the various obligations that accrue to a state when it has violated international law, and will apply those obligations to the Member State refusing nationality, the Member State recognizing that refusal, and the Union itself. Under the Draft Articles on State Responsibility, the first, and the most obvious, obligation of a state, when it is responsible for an internally wrongful

142. E.g., Nold Kohlen-und Baustoffgrobhandlung v. KG Comm'n Eur. Comm'ties, supra note 62; Case C-162/96, Racke GmbH \& Co. v. Hauptzollamt Mainz, 1998 E.C.R. I-03655; Case C-286/90 Ankagemyndigheden v. Poulsen \& Diva Navigation Corp., 1992 E.C.R. I-06019; Joined Cases C-402 and 415/05 P. Kadi \& Al Barakaat Int'l Found. v Council Eur. Union \& Comm'n Eur. Comm'ties, 2008 E.C.R. I-06351 [hereinafter Kadi Case]; Case C-366/10, Air Transp. Case, supra note 62.

143. See, e.g., Treaty on the Functioning of the European Union, Protocol No. 3 on the Statute of the Court of Justice of the European Union art. 3(2), Oct. 26, 2012, 2012 O.J. (C 326) 210, ("Any person who is a Union citizen and fulfils the conditions laid down . . . may submit an application. The Council, acting on a recommendation from the Court of Justice, shall determine the conditions and the arrangements governing the submission and processing of such applications"). 
act or omission is to cease the act ${ }^{144}$ and not repeat it. ${ }^{145}$ Needless to say that the above principles are also equally applicable to all international organizations, as expressed in the Draft Articles on the Responsibility of International Organizations, ${ }^{146}$ including the European Union. ${ }^{147}$ International law governing nationality interprets the obligation to cease as an obligation to restore or reinstate nationality when it is unlawfully denied. ${ }^{148}$ This obligation is equally applicable to international organizations that act unlawfully. ${ }^{149}$ This obligation is not particularly controversial and would require the Member State unlawfully refusing nationality to restore it. Also, as the other Member States and the Union are taking separate, independent action in applying the TFEU, it is arguable that the other Member States and the Union must recognize EU citizenship when a Member State has unlawfully refused nationality. This latter obligation only pertains to EU citizenship because that is the only legal obligation applicable to the Member State; it does not necessarily apply to the recognition of Member State nationality. While it may seem incoherent to recognize

144. See Draft Articles on State Responsibility, supra note 130, art. 29 ("The legal consequences of an internationally wrongful act under this Part do not affect the continued duty of the responsible State to perform the obligation breached."); Draft Articles on State Responsibility, supra note 130, art. 30 ("The State responsible for the internationally wrongful act is under an obligation: (a) to cease that act, if it is continuing").

145. See Draft Articles on State Responsibility, supra note 130, art. 30 ("The State responsible for the internationally wrongful act is under an obligation:... (b) to offer appropriate assurances and guarantees of non-repetition, if circumstances so require").

146. See Draft Articles on the Responsibility of International Organizations, supra note 125, arts. 41(1), 42(2); see also Legal Consequences of the Construction of a Wall in the Occupied Palestinian Territory, Advisory Opinion, 2004 I.C.J. Rep. 136, 167, para. 159 (July 9); U.N.S.C. Res. 662 para. 2 (Aug. 9, 1990) (calling on "all States, international organizations and specialized agencies not to recognize that annexation, and to refrain from any action or dealing that might be interpreted as an indirect recognition of the annexation").

147. See European Community, Declaration on Yugoslavia and on the Guidelines on the Recognition of New States, Dec. 16, 1991, 31 I.L.M. 1485 (reproduced in 31 Int'1 L. Mats. 1485, 1487 (1992)) (articulating the rule of nonrecognition of results of acts of aggression).

148. See Arbitrary Deprivation Report 2015, supra note 111, at 5-6 ("States must provide a child who has been illegally deprived of some or all of the elements of his or her identity with appropriate assistance and protection, with a view to re-establishing speedily his or her identity"). An effective remedy must also be available in the context of arbitrary deprivation of nationality (see $\mathrm{A} / \mathrm{HRC} / 13 / 34, \mathrm{~A} / \mathrm{HRC} / 25 / 28$ and $\mathrm{CRC} / \mathrm{C} / \mathrm{DOM} / \mathrm{CO} / 3-5$ ) ... Where children have, in contravention of international law, been arbitrarily deprived of their nationality and rendered stateless, States must ensure that effective and appropriate remedies are available, including reinstatement of nationality").

149. See Draft Articles on the Responsibility of International Organizations, supra note 125 , arts. 29, 30, 42(2). 
EU citizenship without necessarily recognizing Member State nationality, we can recall that the TFEU only requires Member States to give effect to EU citizenship. ${ }^{150}$

\section{B. Obligation to refuse to recognize an unlawful act}

In addition, when a state acts unlawfully, other states are required to refuse to recognize the unlawful act. ${ }^{151}$ This section will consider whether a Member State or the Union is obliged to constructively recognize EU citizenship when Member State nationality is being refused unlawfully, or whether that is merely a permissible reading of the TFEU. It will also go beyond the obligation of cessation because that obligation only pertains to EU citizenship specifically.

\section{Jus cogens}

States are not permitted to recognize the consequences of jus cogens violations as lawful or render aid to the state concerned to maintain the unlawful situation. ${ }^{152}$ The nonrecognition covers the outcomes of the unlawful acts, and includes reactions that expressly or implicitly recognize the new situation. ${ }^{153}$ The unlawful acts should be treated as having "no legal validity ... [being] considered null and void." 154

The second obligation incumbent on states when there is a violation of jus cogens norms is to require the state to refuse to aid or

150. See supra note 132.

151. See infra Secs. IV.B.1-2.

152. See Draft Articles on State Responsibility, supra note 130, art. 40 ("1. This chapter applies to the international responsibility which is entailed by a serious breach by a State of an obligation arising under a peremptory norm of general international law"); ("2. No State shall recognize as lawful a situation created by a serious breach within the meaning of article 40 , nor render aid or assistance in maintaining that situation"); see also id. art. 41; E. Timor Case (Port. v. Aust'lia), Juris., Judgement, 1995 ICJ Reps. 103-4; Legal Conseq. for Sts. of the Cont. Presence of S. Afr. in Namibia (SW Afr.) notwithstanding SC Res. 276 (1970), Advisory Opinion, 1971 I.C.J. 16 (June 21) [hereinafter Namibia Opinion]. But see SC Res. 276 (1970), Adv. Op., 1971 ICJ Reps. 16, 55-6 (June 21); Cyprus v. Turkey, Appl. No. 25781/94 Eur. Ct. H. R. 17 (2001); Brcko Arbitral Tribunal for Dispute Over the Inter-Entity Boundary in Brcko Area (Rep. Srpska v. Fed. Bosnia \& Herzegovina), Award, paras. 77-78 (Feb. 14, 1997), reprinted at 36 INT'L L. MATS. 396; JOHN DUGARD, RECOGNITION AND THE UNITED NATIONS 135 (1987); HERSCH LAUTERPACHT, RECOGNITION IN INTERNATIONAL LAW 420-21 (1948).

153. See Draft Articles on State Responsibility, supra note 130, art. 41(5).

154. See e.g. U.N.S.C. Res. 662 (Aug. 9, 1990). 
otherwise assist in the unlawful act. ${ }^{155}$ This obligation is more than the obligation to simply not help another state violate its obligations, as covered in Draft Articles on State Responsibility Article 11, ${ }^{156}$ and this provision specifically targets acts that aid in maintaining an unlawful situation. ${ }^{157}$

We will next consider whether the rules against denial of nationality constitute jus cogens norms. It is quite an understatement to say that proving the existence of a jus cogens norm is exceedingly difficult. As Ian Brownlie concluded, "more authority exists for the category of jus cogens than exists for its particular content." 158 A decision of whether an act amounts to a violation of a jus cogens norm is often contained in a UN Security Council decision, ${ }^{159}$ but that is not a necessary condition for the act to have such character. ${ }^{160}$ At a basic level, the rule includes any provision that is non-derogable, ${ }^{161}$ though as a test for jus cogens nature, this statement is likely to be too broad. One approach is to determine which norms protect "the survival of States and their peoples and the most basic human values." 162 More specifically, the rule could qualify as jus cogens if it covers "the principles of liberty, democracy and respect for human rights." 163

155. See Draft Articles on State Responsibility, supra note 130, art. 41(2) ("No State shall recognize as lawful a situation created by a serious breach within the meaning of article 40 , nor render aid or assistance in maintaining that situation.”); $i d$. art. 41(4).

156. See id. art. 11.

157. See id. arts. 41(11), 41(12). See also U.N.S.C. Council Res. 218 (Nov. 23, 1965); U.N.S.C. Res. 418 (Nov. 4, 1977); U.N.S.C. Res. 569 (July 26, 1985).

158. See IAN Brownlie, Principles of Public InTERnational Law 516-17 (1999).

159. See, e.g., U.N.G.A. Res. 68/262 (Mar. 24, 2014); U.N.G.A. Res. 3314 (XXIX), art. 6, para. 3 (Dec. 14, 1974); U.N.G.A. Res. 2734 (XXV), para. 5 (Dec. 16, 1970); U.N.G.A. Res. 2625 (XXV) (Oct. 24, 1970).

160. See Accordance with International Law of the Unilateral Declaration of Independence in Respect of Kosovo, Advisory Op, 2010 I.C.J. Rep. 141 paras. 132-37 (July 22) (separate opinion by Cançado Trindade, J.) [hereinafter Kosovo Declaration]; GabčíkovoNagymaros Proj. (Hung./Slovak.), 1997 I.C.J Reps. 7, 54, 78 (Sept. 25); LAUTERPACHT, supra note 143 , at 421 .

161. See Draft Articles on State Responsibility, supra note 130, art. 40(2) (“In accordance with article 53 of the 1969 Vienna Convention, a peremptory norm of general international law is one which is: 'accepted and recognized by the international community of States as a whole as a norm from which no derogation is permitted and which can be modified only by a subsequent norm of general international law having the same character").

162. See Draft Articles on State Responsibility, supra note 130, art. 40(3) (“. . . substantive rules of conduct that prohibit what has come to be seen as intolerable because of the threat it presents to the survival of States and their peoples and the most basic human values").

163. See Kadi Case, supra note 142, paras. 282, 303 et seq. 
These rules are elevated to having jus cogens quality due to "considerations of morals and international good order." 164

Another approach is to look at commonalities in the existing rules of jus cogens. Examples of norms that have been understood to have this character include the prohibition of aggression, ${ }^{165}$ piracy, ${ }^{166}$ slavery, ${ }^{167}$ genocide, ${ }^{168}$ racial discrimination, ${ }^{169}$ apartheid, ${ }^{170}$ and torture, ${ }^{171}$ as well as rules requiring the basic rules of international humanitarian law, ${ }^{172}$ and self-determination. ${ }^{173}$ In any event, the various experts, negotiators and judiciaries agree that the examples of jus cogens norms were not exhaustive. ${ }^{174}$ Other possible jus cogens norms mentioned at the negotiations over the Vienna Convention on the Law of Treaties ("VCLT") include the rules of state equality, ${ }^{175}$

164. See U.N. Doc. A/CN.4/115 [2 Y.B. Int'1 L. Comm'n 1958] (Fitzmaurice) [hereinafter Fitzmaurice]. See also U.N. Conference on the Law of Treaties, 1st Sess., 54th mtg. at 311, U.N. Doc. A/CONF. 39/11 (May 6, 1968) (Italy: Maresca) ("mankind's awareness of the law" and "the conscience of mankind.).

165. See Draft Articles on State Responsibility, supra note 130, art. 40(4); Fitzmaurice, supra note 164; U.N. Doc. A/CONF. 39/11, supra note 155, at 311 (1968) (Italy: Maresca) (discussing rules that "ensured the maintenance of peace"); U.N.G.A. Conf. Law of Treaties, 1st sess., 52nd mtg, paras. 3, 31, \& 43; 53rd mtg., paras. 4, 9, 15, 16, 35, 48, 59, \& 69; 54th mtg, paras. $9,41,46 ; 55 ; 55$ th $\mathrm{mtg}$, paras. $31 \& 42 ; 56$ th $\mathrm{mtg}$, paras. $6,20,29, \& 51$.

166. Fitzmaurice, supra note 164; Documents of the 5th Session Including the Report of the Commission to the General Assembly, U.N. Doc. A/ON.4/SER.A/1953/Add.1 [2 Y.B. Int'1 L. Comm'n 1953].

167. See Draft Articles on State Responsibility, supra note 130, art. 40(4); 2 Y.B. Int'l L. Comm'n 1953, supra note 166.

168. See Draft Articles on State Responsibility, supra note 130, art. 40(4); Crim (Jer) 40/61 AG v. Eichmann (1961) (Isr.) (reprinted at 36 INT'L L. MATS. 5).

169. See Draft Articles on State Responsibility, supra note 130, art. 40(4); U.N. Doc. A/CONF. 39/11, at 297, 302, 322, 303 (1968) (Lebanon, Poland, Ukraine, \& Uruguay).

170. See Draft Articles on State Responsibility, supra note 126, art. 40(4); U.N.S.C. Res. 217, para. 3 (Nov. 20, 1965).

171. See Draft Articles on State Responsibility, supra note 130, art.40(5); Al-Adsani v. UK, App. No. 35763/97, Eur. Ct. H.R., para. 61 (2001); R. v Bartle \& Comm'r Police for the Metro. [1999] UKHL 17 (appeal) (UK).

172. See Draft Articles on State Responsibility, supra note 130, art. 40(5); U.N. Doc. A/CONF. 39/11, paras. 297, 302, 322, 303 (1968) (Lebanon, Poland, Ukraine, \& Uruguay).

173. See Draft Articles on State Responsibility, supra note 130, art. 40(5); U.N.G.A. Res. 2625 (XXV), Declaration on Principles of International Law concerning Friendly Relations and Cooperation among States in accordance with the Charter of the United Nations, at 121 (Oct. 24, 1970).

174. See Draft Articles on State Responsibility, supra note 130, arts. 40(3), 40(6); Fiztmaurice, supra note 164.

175. See U.N. Doc. A/CONF. 39/11, 311 (1968) (Italy: Maresca) (discussing rules that maintained "the existence and equality of States"). 
freedom of the high seas, ${ }^{176}$ and the prohibition on colonialism (perhaps as part of the right to self-determination). ${ }^{177}$ In addition, the delegates specifically discussed the protection of the person as a jus cogens norm, ${ }^{178}$ which might narrowly cover only certain fundamental human rights ${ }^{179}$ or more broadly cover most human rights. ${ }^{180} \mathrm{CJEU}$ jurisprudence suggests that the obligation of states to admit their own nationals to their territory, ${ }^{181}$ and the rules on the nationality of persons and ships, ${ }^{182}$ would be non-derogable, and in the Kadi case, the CJEU found that "respect for human rights" had jus cogens character. ${ }^{183}$

Some cases of denial of nationality might rise to the level of jus cogens when practiced in the context of other jus cogens obligations. It goes without saying that the refusal or withdrawal of nationality would be a jus cogens violation when that measure was taken on a prohibited ground of discrimination, such as racial, ethnic, religious, etc. Denial of nationality due to racial, ethnic, religion, etc. ${ }^{184}$ Some authorities have opined that the denial of nationality that leads to detention might amount to mistreatment equivalent to cruel, inhuman, or degrading treatment. ${ }^{185}$ However, those practices might not rise to the level of jus cogens because only torture is the one most clearly established as a jus

176. See U.N. Doc. A/CONF. 39/11, at 302 (1968).

177. See U.N. Doc. A/CONF. 39/11, at 297, 302, 322, 303 (1968) (Lebanon, Poland, Ukraine, \& Uruguay).

178. Fitzmaurice, supra note 164; U.N. Doc. A/CONF. 39/11, 311 (1968) (Italy: Maresca).

179. See U.N. Doc. A/CONF. 39/11, at 297, 302, 322, 303 (1968) (Lebanon, Poland, Ukraine, \& Uruguay).

180. See generally Juridical Condition and Rights of Undocumented Migrants, Ad. Op., Advisory Opinion OC-18/03, Inter-Am. Ct. H.R. (ser. A) No. 18 (Sep. 17, 2003).

181. See Case 42/74, Van Duyn v. Home Office, para. 22, 1974 E.C.R. I-1338.

182. See Chen v. Sec'y of St. for the Home Dept., supra note 8, para. 37; Rottmann v. Bayern, supra note 8, paras. 39, 53, 58.

183. See Kadi Case, supra note 142, paras. 282, 303-4.

184. See Gay McDougall (Independent Expert on Minority Issues), Human Rights Council, Promotion and Protection of All Human Rights, Civil, Political, Economic, Social and Cultural Rights, Including the Right to Development, para. 35, U.N. Doc. A/HRC/7/23 (Feb. 28, 2008) (stating that prohibition of discrimination is a non-derogation norm). See also Int'l L. Comm'n, Draft Articles on Nationality of Natural Persons in Relation to the Succession of States, art. 15, II Y.B. INT'L L. COMM'N 37 (1999).

185. See Arbitrary Deprivation Report 2015, supra note 111 (“41... . stateless children in context of migration or forced displacement are more vulnerable to arbitrary and lengthy immigration detention because their lack of a nationality makes it impossible to remove them from the country within a reasonable period of time. Such detention may be considered in violation of both the freedom from cruel, inhuman or degrading treatment and the freedom from arbitrary deprivation of liberty"). 
cogens norm. Although the Human Rights Council concluded that denial of nationality qualified as cruel, inhuman, or degrading treatment, it did not go so far as to argue that nationality denial is itself torture. ${ }^{186}$ However, it is at least conceivable that nationality deprivation, possibly in connection with other aggravating factors, might indeed rise to the level of torture, although examples of such situations are perhaps more difficult to articulate. Lastly, denial of nationality without any means of judicial or administrative review would also be problematic and certainly a violation of fundamental rights, ${ }^{187}$ though it might be a stretch to view that as a jus cogens violation.

Setting aside unlawful nationality denial that implicates other jus cogens norms, this paragraph will consider whether unlawful nationality denial alone would itself amount to a jus cogens violation. The right to a nationality certainly appears to be so critical that it could fall within the lists given above and has been described as nonderogable. ${ }^{188}$ It is unclear whether the UNHCR understands unlawful nationality denial to be a jus cogens norm, though that possibility is not excluded. ${ }^{189}$ The right to nationality is a fundamental right ${ }^{190}$ which is interlinked with and central to the enjoyment of many other human

186. See supra note 185 .

187. See Policy Dep't for Citizens' Rights \& Constitutional Affairs, Eur. Parliament's Comm. on Civil Liberties, Justice and Home Affairs, E.U. and Member States' Policies and Laws on Persons Suspected of Terrorism-related Crimes, E.U. Doc. PE 596.832 (Dec. 18, 2017).

188. See Expelled Dominicans \& Haitians v. Dom. Rep., Preliminary Objections, Merits, Reparations, and Costs, Judgment, Inter-Am. Ct. H.R. (ser. C) para. 253 (Aug. 28, 2014); Girls Yean \& Bosico v. Dom. Rep., Preliminary Objections, Merits, Reparations, and Costs, Judgment, Inter-Am. Ct. H.R. (ser. C), paras. 136-38 (Sep. 8, 2005).

189. See, e.g., Expert Mtg., The Concept of Stateless Persons Under International Law: Summary, para. 18 (May 28, 2010), www.unhcr.org/4cb2fe326.pdf [https://perma.cc/P62VRRG4 ] (comparing nonrecognition of state created through violation of jus cogens norms against use of force to recognition of statelessness created contrary to law).

190. H.R.C. Res. 32/5, supra note 110, para. 1 ("Reaffirm[ing] the right to a nationality of every human person is a fundamental human right enshrined in, inter alia, the Universal Declaration of Human Rights"); Cf. Afroyim v. Rusk, 387 U.S. 253, 257-68 (1967) (deciding that Congress did not have the power to revoke nationality on constitutional grounds). 
rights. ${ }^{191}$ It has been called the "right to have rights." ${ }^{192}$ It does, after all, repetitively appear in virtually every major human rights treaty, ${ }^{193}$ suggesting it is a human rights norm of very special significance. There is a very consistent pattern of resolutions by the Human Rights Council that the human right to nationality is a fundamental human right and that the arbitrary deprivation of it is unlawful. ${ }^{194}$ The Inter-American Court of Human Rights held that the right to a nationality provides a foundation link to a state for protection of human rights. ${ }^{195}$ The Human Rights Committee concluded similarly that the arbitrary revocation of nationality can impact an individual's ability to enjoy all of his or her human rights, ${ }^{196}$ and that the revocation of nationality simply as a pretext to expel a person was a denial of the person's fundamental

191. H.R.C. Res. 32/5, supra note 110, at 2 (Stressing "that all human rights are universal, indivisible, interdependent and interrelated and that the international community must treat human rights globally in a fair and equal manner, on the same footing and with the same emphasis").

192. See, e.g., HANNAH ARENDT, THE ORIgins Of TOtAlitARIANiSM 292-300 (1994). See also Trop v. Dulles, 356 U.S. 86, 101 (1958) (stating that denationalization is "the total destruction of the individual's status in organized society").

193. See ICCPR, supra note 75, art. 24(3); H.R.C. Dec. 2/111, supra note 111; H.R.C. Res. 13/2, supra note 111; H.R.C. Res. 10/13, supra note 79; H.R.C. Res. 7/10, supra note 79; H.R.C. Res. 1998/48, supra note 111; H.R.C. Res. 1999/28, supra note 111; H.R.C. Res. 2005/45, supra note 111; CERD, supra note 75, art. 5(d)(iii); Discrimination Recommendation 2002, supra note116, paras. 13-14; CEDAW, supra note 75, art. 9; CEDAW Gen. Recomm. No. 21: Equality in Marriage and Family Relations, 1994, art. 9; CPMW, supra note 75, art. 29; CRPD, supra note 84, art. 18(1); American Convention on Human Rights ("Pact of San Jose, Costa Rica”) (B-32), Nov, 22, 1969, art. 3, OAS TS No. 36, 144 UNTS 123, reprinted at BASIC DOCUMENTS PERTAining TO Human RightS IN THE INTER-AMERICAN SYSTEM, OAS Doc. OEA/Ser.L.V/II.82 doc.6 rev.1 at 25 (1992) (AmCHR); U.N. Secretary-General, Human Rights and Arbitrary Deprivation of Nationality, U.N. Doc. A/HRC/25/28 (Dec. 19, 2012). See also G.A. Res. 217A(III), Universal Declaration of Human Rights (UDHR), art. 6 (Dec. 10, 1948); American Declaration of the Rights and Duties of Man, OAS Res. XXX (May 2, 1948), art. XVII, OAS Doc. OEA/Ser.L.V/II.82 doc.6 rev.1.

194. See H.R.C. Res. 7/10, supra note 79; H.R.C. Res. 10/13, supra note 79; H.R.C. Res. 13/2, supra note 111; H.R.C. Res. 20/4, U.N. Doc. A/HRC/RES/20/4 (July 16, 2012); H.R.C. Res. 20/5, supra note 79); H.R.C. Res. 26/14 (26 June 2014); H.R.C. Res 32/5, supra note 110.

195. Proposed Amends. to the Naturalization Provision of the Constitution of Costa Rica, Advisory Opinion, OC-4/84, Inter-Am. Ct. H.R. (ser. A), para. 32-35 (Jan. 19, 1984) ("the right to a nationality established therein provides the individual with a minimal measure of legal protection in international relations through the link his nationality establishes between him and the state in question ....").

196. See H.R.C. Res. 32/5, supra note 110, para. 7 (noting "that the full enjoyment of all human rights and fundamental freedoms of an individual might be impeded as a result of the arbitrary deprivation of nationality, and that such individuals are placed in a situation of increased vulnerability to human rights violations"). 
human rights. ${ }^{197}$ Furthermore, the link of nationality with a state has been identified as critical for the individual's sense of identity, ${ }^{198}$ explaining the reason why children have a specially protected right to a nationality, ${ }^{199}$ and in situations of state succession. All of the foregoing suggests that a good case can be argued that the right to a nationality is itself a jus cogens norm.

In addition to the discussion above, it is arguable that the European Union would be without powers to recognize an unlawful refusal of nationality. The Kadi decision of the CJEU attempted to determine the full scope of the obligations imposed by a UN Security Council Resolution which was in turn implemented in the EU Member State through an act of the Union. ${ }^{200}$ The Court took the unusual approach of considering that a treaty cannot be adopted that violates jus cogens so that an international organization, founded by a treaty, also cannot be understood to have powers to adopt acts that violate jus cogens. ${ }^{201}$ On this basis, the Security Council cannot prescribe actions that entail violations of jus cogens. ${ }^{202}$ Essentially, the CJEU used jus cogens norms as a tool for interpreting the powers of an international organization. A similar approach might be taken with regard to EU citizenship and the unlawful denial of Member State nationality. As the TFEU is interpreted using the standard law of treaties, ${ }^{203}$ we might interpret the Union as not having the power to refuse to recognize EU citizenship in such a case.

197. See H.R.C. Res. $32 / 5$, supra note 110 , para. 3 ("that the statelessness of a person resulting from the arbitrary deprivation of his or her nationality cannot be invoked by States as a justification for the denial of other human rights").

198. See H.R.C. Res. $32 / 5$, supra note 110 , para. 11 (reiterating, "that the right to identity is intimately linked to the right of nationality").

199. See H.R.C. Res. 32/5, supra note 110 , para. 9 (reaffirming, "that every child has the right to acquire a nationality, and recognizes the special needs of children for protection against arbitrary deprivation of nationality").

200. See Kadi Case, supra note 142.

201. See id; Vienna Convention on the Law of Treaties, supra note 138, art. 53, 64.

202. See Kadi Case, supra note 142, paras. 53, 64.

203. See Case C-70/09, Hengartner \& Gassner v. Landesregierung Vorarlberg, Judgment, 2010 E.C.R. I-7233, I-7244, para. 36 (2010); Case T-115/94, Opel Austria GmbH v. Council, 1998 E.C.R. II-02739; Case C-162/96, Racke GmbH \& Co. v. Hauptzollamt Mainz, supra note 142. 


\section{Ex injuria jus non oritur}

Returning to the duty of nonrecognition, it is important to note that this duty is not only imposed for jus cogens violations. In fact, it is the general principle of ex injuria jus non oritur, applicable to any unlawful act. In the Namibia advisory opinion, the ICJ found that South Africa was in violation of an obligation imposed by the UN Security Council, ${ }^{204}$ not necessarily a jus cogens norm. Certainly the underlying violation was most likely a jus cogens norm, but the ICJ did not need to reach that finding in order to invoke ex injuria jus non oritur for violating a binding Security Council resolution. ${ }^{205}$ In addition to the Namibia situation, the UN Security Council has demanded nonrecognition for a number of other cases. ${ }^{206}$

But the obligation of nonrecognition is not limited to only UN Security Council resolutions; it accrues to any violation of international law. ${ }^{207}$ For example, in the Gabčikovo-Nagymaros Project case, the

204. See Namibia Opinion, supra note 152 ("The member States of the United Nations are, for the reasons given in paragraph 115 above [binding nature of U.N.S.C resolutions], under obligation to recognize the illegality and invalidity of South Africa's continued presence in Namibia. They are also under obligation to refrain from lending any support or any form of assistance to South Africa with reference to its occupation of Namibia, subject to paragraph 125 below").

205. See id. paras. 117-18 (June 21).

206. See Kosovo Declaration, supra note 160, para. 14 (separate opinion by Koroma, J.) As subsidiary bodies of the Security Council, they [the international territorial administration in Kosovo] possess limited authority derived from and circumscribed by [UN Security Council] resolution 1244 (1999). No power is vested in any of those bodies to determine the final status of Kosovo, nor do any of them have the power to create other bodies which would have such a power. Accordingly, when the Assembly of the Provisional Institutions of Self-Government of Kosovo purported to declare independence on 17 February 2008, they attempted to carry out an act which exceeded their competence. As such, the declaration is a nullity, an unlawful act that violates express provisions of Security Council resolution 1244 (1999). It is ex injuria non oritur jus (internal citations omitted).

U.N.S.C. Res. 216 (1965); U.N.S.C. Res. 217 (1965); U.N.S.C. Res. 277 (1970); U.N.S.C. Res. 242 (1967); U.N.S.C. Res. 288 (1970); U.N.S.C. Res. 476 (1980); U.N.S.C. Res. 478 (1980); U.N.S.C. Res. 491 (1981); U.N.S.C. Res. 836 (1993); U.N.G.A. Res. 3314 (XXIX); Draft Articles on State Responsibility, supra note 130, art. 41(8).

207. See Mavrommatis Jerusalem Concessions (Gr. v. UK), Judgment, 1925 P.C.I.J. (ser. A) No. 5, at 50 (Mar. 26); Case Concerning the Factory at Chorzów (Germ. v. Pol.) (Claim for Indemnity) (Juris.), Judgment, 1927, P.C.I.J. (ser. A) No. 9, at 31 (July 26); L. Status of E. Greenland (Den. v. Nor.), Judgment, 1933 P.C.I.J. (ser. A/B) No. 53, at 95 (Apr. 5) (Anzilotti, J., dissenting) ("[A]n unlawful act cannot serve as the basis of an action at law. . .."); Divers. of Water from the Meuse (Neth. v. Belg.), Judgment, 1937 P.C.I.J. (ser. A/B, no 70); Divers. of Water from the Meuse (Neth. v. Belg.) 1937 PCIJ, Ser. P.C.I.J. (ser. C, No 81), para. 240; U.S. 
ICJ also found that ex injuria jus non oritur applied generally and, in that case, applied to the rather mundane violation of a treaty for the construction of infrastructure. ${ }^{208}$ Also, in the Namibia opinion held that the obligation of nonrecognition applies to all states in the world, not only to UN Member States. ${ }^{209}$ Since non-members of an organization cannot be legally responsible for violating Security Council resolutions, it cannot be the normative force of the resolution that required states to refuse to recognize the legal effects of Namibia's actions. Lastly, we find the same conclusion implied in the views of the Special Rapporteur on the Law of Treaties. In preparing his report, Lauterpacht, quoting McNair, concluded that a treaty would be rendered void when it had as its object any violation of customary international law, not only jus cogens norms or Security Council resolutions. ${ }^{210}$ For these reasons, we need not necessarily find that the right to a nationality constitutes a jus cogens norm in order to apply the principle of ex injuria jus non oritur.

Following Namibia, the precise parameters of the nonrecognition obligation are wide-ranging. Primarily, other states must regard the official acts of the state pertaining to the unlawful conduct as "invalid," 211 and "void" on the international plane. ${ }^{212}$ Specifically, the

Dipl. \& Consular Staff in Tehran (U.S. v. Iran), Judgment, 1980 I.C.J. 51, 58 (May 24) (Morozov \& Tarazi, JJ., dissenting, at 53-55, 62-63); Military \& Paramilitary Activities in and Against Nicaragua (Nicar. v. U.S.), Judgment, 1986 I.C.J. 14, para. 270; (June 27) (Schwebel, J., dissenting); Accord. with Kosovo Declaration, supra note 160, para. 132-37 (separate opinion by Cançado Trindade, J.) ("According to a well-established general principle of international law, a wrongful act cannot become a source of advantages, benefits or rights for the wrongdoer : ex injuria jus non oritur" although applying the principle only to cases of "grave breaches" or "atrocities perpetrated against the population") (internal citations omitted). See generally William Thomas Worster, The Effect of Leaked Information on International Legal Norms, 28 AM. UNIV. INT'L L. REV. 443 (2013).

208. See Gabčíkovo-Nagymaros Project (Hung. / Slovak.), Judgment, 1997 I.C.J. 7, 76, para. 133 (Sep. 25).

The Court, however, cannot disregard the fact ... Nor can it overlook that factual situation ... This does not mean that facts - in this case facts which flow from wrongful conduct determine the law. The principle ex injuria jus non oritur is sustained by the Court's finding that the legal relationship created by the 1977 Treaty is preserved and cannot in this case be treated as voided by unlawful conduct.

209. See Namibia Opinion, supra note 152, para. 126.

210. See II YB Int'1 L. Comm'n 154 (1953) (Lauterpacht citing McNair) (“It is believed that a treaty between two States the execution of which contemplates the infliction upon a third State of what customary international law regards as a wrong is illegal and invalid ab initio."

211. See Namibia Opinion, supra note 152 , para. 125.

212. See U.N.S.C. Res. 662, para. 1 (Aug. 9, 1990) (“[N]ull and void”). 
other states may not enter into treaties pertaining to the unlawful act, ${ }^{213}$ cannot conduct economic relations pertaining to the unlawful act, ${ }^{214}$ and cannot send diplomatic or consular missions in support of the unlawful act. ${ }^{215}$

However, the risk is that the refusal to recognize official acts might harm individuals. In the Namibia advisory opinion, the ICJ concluded that there was a different consideration for "general conventions such as those of a humanitarian character, the nonperformance of which may adversely affect the people of [the state]." 216 Where the nonrecognition of official acts would operate to the detriment of the population, those acts may be recognized exceptionally. ${ }^{217}$ This conclusion leads to the dissonance that an official act of state may be lawful and valid for some purposes, but not lawful or valid for other purposes. However, this conclusion makes sense, because otherwise states could not apply, for example, international humanitarian law to situations arising from unlawful aggression, because the aggression was unlawful and "void." $218 \mathrm{We}$

213. See Namibia Opinion, supra note 152, para. 122. Additionally, other states must suspend operation of existing treaties pertaining to the unlawful conduct. Id.

214. See id. para. 124.

215. See id. para. 123.

216. See id. para. 122. See also Cyprus v. Turkey, supra note 152, paras. 4, 5; Hopkins v. Mex., 4 U.N. REP. INT'L ARB. AwARDS 41 (1926); R. (on the application of Kibris Turk Hava Yollari) v Secretary of State for Transport, Case No: CO/3512/2007 [2009] E.W.H.C. 1918 (Admin); [2010] 1 All E.R. (Comm) 253 (2009) (Eng.); Emin v Yeldag [2002] 1 F.L.R. 956 (UK); B v. B (Divorce: N. Cyprus) [2000] 2 F.L.R. 707, [2001] 3 F.C.R. 331 (UK); Somalia v. Woodhouse Drake \& Carey (Suisse) SA (The Mary) [1993] QB 54 (UK); Reel v. Holder [1981] 1 W.L.R. 1226; [1981] 3 All E.R. 321; (1981) 125 S.J. 585 (UK); Hesperides Hotels Ltd v. Aegean Turk. Holidays Ltd [1978] 1 QB 205 (UK); In re Al-Fin Corp.'s Patent, [1970] Ch 160, 177-81 (UK); Luigi Monta of Genoa v Cechofracht Co [1956] 2 QB 552; [1956] 3 WLR 480 (QB Div., Jun. 14, 1956) (Sellers, J.); RESTATEMENT (THIRD) OF FOREIGN RELATIONS § 205(3) (1987).

217. See Namibia Opinion, supra note 152, para. 125 ("should not result in depriving the people of [the state] of any advantages derived from international co-operation ... [the] invalidity [of official acts] cannot be extended to those acts, such as, for instance, the registration of births, deaths and marriages, the effects of which can be ignored only to the detriment of the inhabitants of the Territory").

218. See Malcolm Shaw, International Law 807-8 (1997); Enzo Canizzaro, Contextualizing Proportionality: Jus Ad Bellum and Jus in Bello in the Lebanese War, 88 INT'L REV. RED CROSS 791 (2006); Christopher Greenwood, The Relationship Between Jus ad Bellum and Jus in Bello, 9 REV. INT'L STUDIES 227 (1983). 
would not want the legal nullification of unlawful acts to excuse an actor from responsibility for other consequential obligations. ${ }^{219}$

For the topic of this Article on unlawful denial of Member State nationality and EU citizenship, the obligation of nonrecognition could operate to render certain individuals as enjoying Member State nationality constructively and EU citizenship accordingly. If indeed, the refusal of nationality is unlawful as argued above, then the denial of that nationality must be "invalid." 220 If the denial is invalid, then the Member State must be deemed to have granted nationality de jure, even if it has not done so de facto. ${ }^{221}$ In turn, if the Member State is deemed to have granted nationality de jure, then EU law commands that the individual also acquires EU citizenship.

There is some precedent for recognizing a person as having a nationality when the person, in fact, does not. ${ }^{222}$ For example, states have recognized the "nationality" of individuals from Taiwan, Northern Cyprus, Palestine, and colonial mandates for certain

219. Some questionable, quasi-states, while not recognized as states, are still held to human rights and international humanitarian law. See Prosecutor v. Tadić, Case No. IT-94-1-A, Judgment, paras. 115-46 (Int'l Crim. Trib. for the Former Yugo., Appls. Ch., July 15, 1999); Gould et al. v. PLO \& Palestinian Auth., Case No. 04-CIV.-00397 (GBD) (SDNY, Feb. 25, 2015); ANDrew Clapham, Human Rights Obligations of NON-State ACtORS 291-444 (2006); see generally JeAn S. PiCtet, The Geneva Conventions of 12 August 1949, COMMENTARY, I GENEVA CONVENTION FOR THE AMELIORATION OF THE CONDITION OF THE Wounded AND Sick IN ARMed ForCeS IN THE Field (1952); Philip Alston, The "Not-aCat" Syndrome: Can the International Human Rights Regime Accommodate Non-State Actors?, in., NON-STAte ACtORS AND Human Rights 3-4 (Philip Alston ed., 2005); Rep. China [on Taiwan Island], Ofc Pres., President Ma Attends Press Conference Unveiling English Version of Taiwan's First National Human Rights Report under the ICCPR and ICESCR (Dec. 18, 2012) available

http://english.president.gov.tw/Default.aspx?tabid=491\&itemid=28855\&rmid=2355

[https://perma.cc/LMJ7-M4D5] ; Rep. China [on Taiwan Island], Ofc Pres., President Ma Holds Press Conference on the Release of Taiwan's First Human Rights Report (Apr. 20, 2012) available

http://english.president.gov.tw/Default.aspx?tabid=491\&rmid=2355\&itemid=27092

[https://perma.cc/U6YV-PCNB].

220. See Namibia Opinion, supra note 152, para. 125.

221. See U.N. High Commissioner for Refugees, Expert Mtg. The Concept of Stateless Persons under International Law, para. 20 (May 28, 2010), www.unhcr.org/4cb2fe326.pdf [https://perma.cc/GR63-53T3] ("[Statelessness] refers to a factual situation, not to the manner in which a person became stateless").

222. See generally William Thomas Worster, Relative International Legal Personality of Non-State Actors, 42 BROOKLYN J. INT'L L. 207 (2016). 
purposes. ${ }^{223}$ Also, the Human Rights Committee, in the context of the right to return to one's own country, has held that individuals unlawfully denied their nationality still retain the right to return to their "own country," despite no longer actually holding their state's nationality. 224

This conclusion on the constructive acquisition of EU citizenship is strengthened by the ICJ's statements in Namibia that treaties must be applied or suspended to the degree to which they pertain to the unlawful conduct. ${ }^{225}$ This author has already argued that the TFEU can be read to permit recognition of EU citizenship despite the unlawful denial of Member State nationality, simply by another Member State making a good faith determination that a person holds EU citizenship, even though in disagreement with another Member State. For the obligation of ex injuria jus non oritur under discussion in this section, other states cannot enter into economic and other relations with the state pertaining

223. See U.N. Compensation Commission Dec., U.N. Doc. S/AC.26/1992/10, art. 5.2 (June 26, 1992) (permitting third parties to submit claims on behalf of individuals who cannot get their claims submitted by a government); U.S. DEP'T OF STATE, 8 ForeIGN AFFAIRS MANUAL AND HANDBOOK, 403.4-4(D), 403.4-7(C) (providing passport instructions to agency officials in accordance with United States' recognition policy and general consistency with current sovereignty regarding Republic of China on Taiwan Island and the Turkish Republic of Northern Cyprus) [hereinafter FAM]; Caglar v. Billingham (Insp. of Taxes) [1996] STC 150 (SCD) at 151 (Eng.); 584 Hansard HL col. WA205 (Jan. 15, 1998); 304 Hansard HC col. WA277 (Jan. 15, 1998); JAMES CRAWFORD, THE CREATION OF STATES IN INTERNATIONAL LAW 31 (2006) (regarding "A" Mandated Territories); Linda A. Taylor, The United Nations Compensation Commission, in REPARATIONS FOR VICTIMS OF GENOCIDE, WAR CRIMES AND CRimes AgAinst HumAnity 197, 202 (Carla Ferstman, Mariana Goetz \& Alan Stephens eds., 2009); see also Paul Koring, Palestine exists for a select few Canadians, THE GLOBE \& MAIL (Sep. 20, 2011), http://www.theglobeandmail.com/news/world/palestine-exists-for-a-selectfew-canadians/article594913 [https://perma.cc/JZB7-6MCM] (explaining that Palestine exists as a valid "Country of Birth" for Canadians despite their government not recognizing Palestine as a state). But see U.S. DEP'T OF STATE, 7 FOREIGN AFFAIRS MANUAL AND HANDBOOK, 403.4$4(A)(h)$ (prohibiting "Palestine" as a valid country of birth after 1948 and requiring instead "West Bank," "Gaza Strip," or "Israel").

224. Gen. Comm. on the Freedom of Movement, Human Rights Comm. on its SixtySeventh Session held on Oct. 18, 1999, para. 20, U.N. Doc. CCPR/C/21/Rev.1/Add.9 (Nov. 1, 1999):

Thus, the persons entitled to exercise this right ... embraces, at the very least, an individual who, because of his or her special ties to or claims in relation to a given country, cannot be considered to be a mere alien. This would be the case, for example, of nationals of a country who have there been stripped of their nationality in violation of international law ....

225. See Namibia Opinion, supra note 152, para. 122 (June 21). Additionally, states must suspend operation of existing treaties pertaining to the unlawful conduct. Id. 
to the unlawful conduct. ${ }^{226}$ This obligation means that the economic and other rights in the TFEU must be applied as if the unlawful act has not occurred. To refuse to honor the individual's constructive EU citizenship would be to enter into an economic relationship that honors the refusal of EU citizenship. Furthermore, states cannot send diplomatic and consular missions that support or give implied validity to the unlawful acts. This obligation suggests that the officers of the state must discharge their functions in a manner not recognizing the unlawful act. Immigration officers, consuls giving protection, etc. must treat the person whose nationality is unlawfully denied as having constructive EU citizenship or they will be giving effect to the unlawful state action. ${ }^{227}$

In addition to all of the considerations above, the ICJ's Namibia exception for issues of humanitarian nature also commands that we honor constructive EU citizenship. ${ }^{228}$ Certainly, giving legal effect to a state's unlawful denial of nationality would adversely affect individuals. Where the nonrecognition of official acts would operate to the detriment of the population, then they may be recognized.229 Because this is an exception for the benefit of people, constructive nationality and EU citizenship should be recognized where they work to the person's advantage (e.g., freedom of movement in the European Union) and not recognized where they work against the person (e.g., additional protections accruing to stateless persons under the Statelessness Convention). Even if unlawful deprivation of nationality is unlawful, states can still recognize the case as the creation of statelessness, ${ }^{230}$ while treating the individual as if he or she had a

226. See id., para. 124

227. See id., para. 123

228. See id., para. 122

229. See id., para. 125

230. See U.N.H.C.R., Expert Meeting, The Concept of Stateless Persons under International Law, para. 18 (May 28, 2010), www.unhcr.org/4cb2fe326.pdf [https://perma.cc/L43D-68XM].

[W] here a deprivation of nationality may be contrary to rules of international law, this illegality is not relevant in determining whether the person is [stateless]... The alternative approach would lead to outcomes contrary to the ordinary meaning of the terms [on statelessness] ... This does not, however, prejudice any obligation that States may have not to recognize such situations as legal where the illegality relates to a violation of jus cogens norms. 
nationality for other purposes, ${ }^{231}$ because a statelessness determination examines the factual situation, not the method of loss of nationality. ${ }^{232}$

One final thought on this matter is that the underlying reasoning of Nottebohm might permit a state to recognize EU citizenship even without the need to resort to ex injuria jus non oritur. In Nottebohm, the ICJ held that states are not required to recognize the nationality of other states when the grant of nationality is not in compliance with international law, which requires a "genuine link." 233 Actually, the Court held that all public acts of a state, including the grant of nationality among others, cannot demand unquestioning recognition, when contrary to international law. ${ }^{234}$ If an EU Member State determined that such an unlawful act by a sister Member State occurred and decided to treat the individual as if he had EU citizenship, then this act should be permissible.

The possibility to refuse to recognize other Member State acts does not violate existing EU law. The situation is fundamentally different from Rottmann and Micheletti where the duty of sincere cooperation within the European Union requires states to give effect other state's acts. Rottmann was concerned with the revocation of Member State nationality and the impact on EU citizenship. ${ }^{235}$ Micheletti was focused on the refusal to recognize another Member State's nationality with serious negative implications for EU citizenship. ${ }^{236}$ This proposal in this article is quite different; it concerns the refusal to recognize a Member State's denial of nationality, in favor of EU citizenship for the individual. This situation does not raise the same implications for EU citizenship and sincere cooperation that the denials of EU citizenship in Rottmann and Micheletti did, because it protects EU citizenship from wrongful denial. Thus, this proposal is in alignment with Rottmann and Micheletti.

Finally, the obligation to refuse to recognize an unlawful denial of nationality applies to all states. In the Namibia opinion, the ICJ concluded that the obligation of nonrecognition applies to all states in the world, not only to UN Member States. ${ }^{237}$ While this might be based

231. See FAM, supra note 223, at 41.104, 41.113; Crawford, supra note 221, at 31. See also Caglar v. Billingham, supra note 223, at 151.

232. U.N.H.C.R., supra note 218 , at 4 para. 20

233. See Nottebohm Case, supra note 23.

234. See id.

235. Rottmann v. Bayern, supra note 8, paras. 42-5, 55-56.

236. $I d$.

237. See Namibia Opinion, supra note 152, para. 126. 
on the special nature of the United Nations, the Court does not articulate it as such. For this reason, the obligation to recognize constructive EU citizenship applies equally to states that are not members of the European Union as it does to EU Member States. While other EU Member State may have more obvious obligations such as respecting free movement and providing for participation in EU parliamentary elections, non-EU states will need to give certain benefits to the individuals as part of their EU citizenship. For example, to the degree to which other states have accepted the right of any EU Member State's mission to exercise diplomatic assistance and to protect any EU citizen, such practice should be respected for constructive EU citizens. There may also be other benefits for travel visas, scholarship funding, and so on, available in third states to EU citizens.

\section{CONCLUSION}

This Article has concluded that the unlawful revocation or refusal of Member State nationality cannot have a legal effect within the EU legal order and that an individual should have his or her EU citizenship recognized by other states, despite the denial of Member State nationality. An individual acquires EU citizenship when he or she holds Member State nationality. While the acquisition of EU citizenship is dependent on Member State nationality, EU citizenship is largely independent of Member State nationality for other purposes. This dual nature is in keeping with EU citizenship being a person's fundamental legal status within the Union, placing that person into a direct legal bond with the Union.

Because the acquisition of EU citizenship is dependent upon the acquisition of Member State nationality, the nationality laws of the Member State are critical. The Member States retain considerable discretion in determining which persons are eligible for acquisition and retention of nationality. But this discretion is not unlimited. For example, Member States are not free to impose discriminatory rules for the acquisition of their nationality. Such a rule would, in effect, mean that the Union had adopted discriminatory rules for the acquisition of EU citizenship, through the instrumentality of the Member State. Clearly, international and European human rights law would prohibit such a practice. Discrimination is only one limitation and other limitations include protections from statelessness and the arbitrary 
revocation of nationality, as well as the protection of other human rights, such as the right to an identity.

This Article has examined the impact on EU citizenship when a Member State persists in imposing unlawful nationality laws. EU law requires states to act with sincere cooperation in implementing their EU obligations, including adopting nationality laws. While Member States may be prohibited under law from adopting certain nationality measures, those laws may not necessarily have domestic effect. In such cases, other Member States, and the Union itself, should not be required to recognize the unlawful act. The ability to refuse recognition of unlawful acts has a long pedigree in international law and states have exercised this right for any violation of international law, not only jus cogens obligations. There is a possibility for interpreting the TFEU to grant EU citizenship despite the unlawful denial of Member State nationality, and the duty of sincere cooperation does not otherwise require Member States to recognize a denial of nationality. Therefore, the other Member States and the Union itself will be under a duty to refuse legal effect to the unlawful act, a duty that EU law will not excuse. The consequence will be that the other Member States and the Union will recognize an individual as having de jure EU citizenship notwithstanding the lack of de facto Member State nationality.

There are several ways in which this practice might arise. One possibility is that, following the denial of Member State nationality, the individual could request a referral to the CJEU. Similarly, if the individual was physically in a different EU Member State and applied for rights deriving from his or her claim to EU citizenship, then he or she could appeal the denial, and, again, request a referral to the CJEU if necessary. Of course, either one of these processes could be abbreviated if the Member State resolved the question of EU citizenship at a lower appellate level. Yet another possible scenario is for a claimant to EU citizenship to apply directly to the Union for some exercise of EU citizenship rights, such as EU civil servant employment, and request the Union to recognize his or her EU citizenship despite the Member State refusing nationality. Obviously, this practice may cause some logistical difficulties, such as establishing EU citizenship without possessing a Member State passport, but these are merely evidentiary complications. This author has previously argued that the Union should take the step of documenting EU citizenship separately from Member State nationality, in keeping with its distinct fundamental status, and this article argues in favor of that practice again. 
In summary, while EU Member States serve as gatekeepers to EU citizenship by exercising their nationality laws, they may not impose nationality laws that are unlawful. Such unlawful acts cannot have lawful consequences. Not only does the Member State violate European and international law in doing so, but the recognition of its unlawful act would implicate the other Member States and the Union. Those other actors are bound by international law to refuse to recognize unlawful acts as having lawful consequences, so they would violate international law to act otherwise. In addition, in so far as the recognition of the unlawful nationality refusal must be given effect within the other Member States and Union legal order, those other actors would be violating other primary rules of international law. All of these arguments force us to conclude that, should an EU Member State unlawfully deny any person its nationality, and thus EU citizenship, the other EU Member States and the Union must nonetheless give effect to EU citizenship. 